February 2023

\title{
"Do Standard-Essential Patent Owners Behave Opportunistically? Evidence from U.S. District Court Dockets"
}

Brian J. Love, Yassine Lefouili, Christian Helmers 


\title{
Do Standard-Essential Patent Owners Behave Opportunistically? Evidence from U.S. District Court Dockets*
}

\author{
Brian J. Love ${ }^{a}$ \\ Yassine Lefouili ${ }^{b}$ \\ Christian Helmers $^{a}$ \\ a Santa Clara University \\ ${ }^{b}$ Toulouse School of Economics, University of Toulouse Capitole
}

February 7, 2023

\begin{abstract}
To what extent and with what effect do owners of standard-essential patents (SEPs) "hold-up" companies that produce standard-compliant products? To explore this question, we construct measures of opportunistic patent licensing behaviors using detailed information collected from the dockets of U.S. patent cases filed (2010-2019) to enforce SEPs and a matched sample of non-SEPs. Overall, we find evidence of opportunistic behavior by the patent enforcer in approximately 77\% of SEP and 65\% of non-SEP assertions in court. The figures mask important heterogeneity. There is significantly more opportunistic conduct aimed at increasing a potential licensee's loss if the patent enforcer prevails in court: 35\% of SEP assertions vs. $10 \%$ of non-SEP assertions. In contrast, conduct that increases a potential licensee's litigation costs is less common and the difference between SEP assertions (8\%) and non-SEP assertions (6\%) is small. We also show that opportunistic behavior is associated with case outcomes, with the effect on settlement depending on the type of opportunistic behavior. Behavior that increases a potential licensee's litigation costs is associated with an increase in the probability of settlement, while behavior that increases a potential licensee's loss if the patent enforcer prevails in court is negatively associated with settlement.
\end{abstract}

KEYWORDS: Litigation, standards, patents, hold-up, U.S.

\footnotetext{
*We thank the Searle Center on Law, Regulation, and Economic Growth for making their data on StandardEssential Patents available to us. We also thank Fabian Gaessler, Jorge Contreras, Jorge Padilla, Cesare Righi, and participants at TPRI IP Days 2021, IPSDM 2022, and the TUM Workshop on SEP Licensing for their useful comments and suggestions. Christian Helmers and Brian Love acknowledge financial support from the Innovators Network Foundation. Yassine Lefouili acknowledges funding from the Agence Nationale de la Recherche under grant ANR17-EURE-0010 (Investissements d'Avenir program). Corresponding author: yassinelefouili@gmail.com.
} 


\section{Introduction}

How should patent owners be compensated when they obtain patent rights that cover some aspect of a widely used technology standard? Perhaps no issue has drawn more attention from the international patent community in the last decade. However, despite years of scholarly debate, multi-national litigation, and scrutiny from competition regulators, no consensus answer has emerged. On one side of the divide, scholars, courts, and policymakers have urged the adoption of special rules and procedures for licensing standard-essential patents (SEPs), given the (at least theoretical) ability of SEP owners to leverage their patent rights (post-standardization) to extract royalties that exceed the (pre-standardization) value of their inventions by "holding up" companies that sell standard-compliant products and services. ${ }^{1}$ On the other side, additional commentators, judges, and regulators have urged, often citing an incentive for licensees to "hold out" and delay licensing SEPs absent rules with substantial coercive effect, a more laissez faire approach consistent with traditional patent enforcement. ${ }^{2}$

A key reason for this divide in the literature is that, while theory predicts the existence of hold-up (Shapiro, 2001; Lemley and Shapiro, 2007), verifying its existence empirically has proven challenging (Contreras, 2019). Indeed, it has been said that "actual evidence of hold-up remains scant" (Delrahim, 2019) ${ }^{3}$ in the existing literature, with some going so far as to suggest that hold-up does not exist at all or has no significant impact on innovation (Galetovic et al., 2015; Barnett, 2017).

In turn, a fundamental reason for this lack of empirical evidence is a paucity of readily available, public information on the behavior of SEP licensors. $4^{4}$ The market for licensing SEPs-like the market for transferring patent rights more generally-largely operates in the dark. As private contracts, virtually all deals are negotiated in secret and thereafter rarely come to light (Love and Helmers, 2022). Consequently, data on SEP licensing positions and tactics, proposed and agreed upon terms, and royalty structures and amounts are dispersed among myriad companies that are generally obligated to keep what they know confidential.

In this paper, we explore a heretofore underutilized source of information about SEP licensing behavior: U.S. court dockets. While SEP licensing often takes place outside of court, a significant fraction of disputes between SEP licensors and licensees lead to litigation, and these court cases in turn produce a trove of public information about

\footnotetext{
${ }^{1}$ See for example Lemley (2007); DOJ/FTC (2007); FTC (2011); Scott Morton and Shapiro (2016).

${ }^{2}$ See for example Epstein and Noroozi (2017) and USPTO/NIST/DOJ 2019 joint policy statement on remedies for standard-essential patents. Teece (2018) additionally considers incentives to participate in the standard development process itself.

${ }^{3}$ Speech by now-former Assistant Attorney General Makan Delrahim at the Licensing Executives Society 2019 Annual Meeting, Phoenix, AZ, October 21, 2019.

${ }^{4}$ There are, of course, other explanations (Shapiro and Lemley, 2020). For one, potential licensees may anticipate hold-up and structure their activities so as to avoid or minimize it (e.g., by abandoning plans to produce standard-compliant products or engage in cross-licensing). In addition, hold-up is inherently hard to measure. While potential SEP licensees commonly allege that SEP licensors charge unreasonably high royalty rates, it is no easy task to assess whether a royalty rate is indeed unreasonable and, if so, to what degree hold-up is responsible.
} 
the positions and behaviors of the litigants..$^{5}$ We review the dockets of the population of patent cases filed in U.S. district courts between 2010 and 2019 to assert or challenge one or more patents declared essential to a large number of technology standards administered by a total of 16 standard setting organizations (SSOs) and patent pools.

While these cases directly involve only a small minority (about three percent) of all declared SEP families, their outcomes and the patents involved are of disproportionate importance. SEPs selected for litigation are commonly alleged to account for the majority of the value of the licensor's entire SEP portfolio ${ }^{6}$ and SEP case settlements typically take the form of portfolio-wide licenses that confer rights to all of the licensor's relevant patents (not just the handful that were litigated in the case) ${ }^{7}$ In addition, royalty rates disclosed or awarded in litigation are, thereafter, widely employed as benchmarks in SEP licensing negotiations and future court cases. Lawsuits and the subset of patents involved, therefore, play a critical and central role in the overall SEP licensing ecosystem.

This fact has drawn many to study SEP litigation, though to date the existing literature has largely focused on a small number of highly selected cases that were litigated to appellate decisions.$^{8}$ In a recent noteworthy exception, Lemley and Simcoe (2019) analyze 537 U.S. district court cases that involve 355 SEPs declared to 13 SSOs. They compare these suits with a matched sample of cases involving non-SEPs (NSEPs), and find that declared SEPs are significantly less likely to be found infringed. In another exception, Contreras (2017) studies 118 U.S. district court cases filed between 2000 and 2015 to enforce patents declared essential to seven standards. He finds that threequarters of SEP assertions in his database were filed by non-practicing entities (NPEs).

Our work expands upon these existing studies to examine dockets in much greater detail and for a much larger set of SEPs litigated over an entire decade. In particular, we advance the literature by using detailed information collected from the dockets of U.S. patent suits to construct indicators of potential "hold-up" by litigants enforcing SEPs and a matched sample of NSEPs. Using these measures, we examine the prevalence of potential hold-up in patent disputes and consider their determinants. In addition, we analyze their effects on case outcomes in the form of settlements.

\footnotetext{
${ }^{5}$ With the notable exception of evidence on royalty rates paid by third parties to license SEPs. Details concerning specific licensing negotiations and terms are virtually always redacted or filed "under seal."

${ }^{6}$ In Ericsson, Inc. v. D-Link Corp., for example, Ericsson's argument that the six U.S. patents asserted in the case accounted for "at least 50 percent of the total value of the Ericsson 802.11 Portfolio" was approved by the court as "a realistic and thorough attempt to apportion revenue to only the asserted patents.” No. 6:10-cv-473 (E.D. Tex. May 20, 2013).

${ }^{7}$ Commenting on licensing practices in the cellular communications industry, Blecker et al. (2016) state that "[b]ecause of the potentially large number of patents involved, the transaction costs associated with licensing patent-by-patent, country-by-country, product-by-product would be astronomical." Accordingly, parties conclude an "agreement for a whole-portfolio license, which necessarily includes a license to all of the patent holder's SEPs." See also Apple, Inc. v. Motorola, Inc., 757 F.3d 1286, 1323 (Fed. Cir. 2014) (summarizing Motorola's contention that "licensing one patent from a large SEP portfolio was not a typical industry practice" because "[i]n the 'real world,' . . . SEPs are only licensed in large portfolios").

${ }^{8}$ Most commonly, Microsoft, Inc. v. Motorola, Inc., In re Innovatio IP Ventures, and TCL Communication Technology v. Ericsson, Inc., which have been oft cited as evidence of hold-up, and Ericsson, Inc. v. D-Link Systems Inc., which is frequently cited as evidence of the opposite (Contreras, 2019).
} 
Consistent with the literature's expansive use of the term hold-up in the patent enforcement context (Shapiro and Lemley, 2020), our measures broadly cover a wide variety of strategies - which we refer to as "opportunistic" conduct - that a patent enforcer could employ to place pressure on a potential licensee by increasing (i) the cost of contesting the patent enforcer's claims of infringement or (ii) the patent enforcer's recovery/prospective licensee's loss at the conclusion of litigation if the patent is found valid and infringed. Moreover, we also distinguish between opportunistic conduct that is generally available to both SEP and NSEP licensors and conduct that is uniquely available to SEP licensors.9

Using these data, we assess the determinants and effects of potential hold-up using two complementary approaches. First, we examine variation within our sample of SEP cases. This approach allows us to analyze the occurrence and effect of opportunistic conduct within the specific context of SEP licensing, that is, by comparing SEP licensing disputes in which opportunistic conduct did or did not occur. It also allows us to analyze opportunistic conduct that is specific to the SEP context. Nonetheless, this analysis is limited in that it does not produce results relative to a baseline. Second, we examine variation across SEP and matched NSEP cases. This approach provides comparative results, yet forecloses the analysis of behaviors and determinants that have no reasonable counterpart in the world of NSEP acquisition and enforcement.

Considered in the aggregate, our data reveal that opportunistic conduct is common in both SEP and NSEP litigation, and relatively more common in the SEP context. Overall, we observe evidence of at least one measure of opportunistic conduct in connection with $77 \%$ of SEP and $65 \%$ of NSEP assertions. At the same time, our results also reveal important hetereogeneity in the frequency with which different forms of potential hold-up (actually or allegedly) occur, both generally and across SEP and NSEP cases. In particular, among SEP assertions, we find relatively more evidence of tactics aimed at increasing accused infringers' potential loss (35\%) than tactics aimed at increasing accused infringers' cost of defense (8\%). Comparing across SEP and NSEP cases, we observe a relatively large gap in the prevalence of loss-related hold-up measures (35\% of SEP assertions vs. $10 \%$ of NSEP assertion) compared to costs-related hold-up measures, evidence of which appears in just $8 \%$ of SEP and 6\% of NSEP assertions.

In order to study the effect of these different types of opportunistic conduct on settlement, we present a simple model of patent litigation. Specifically, our model predicts that opportunistic behaviors that mainly aim to increase the accused infringer's costs of litigation tend to increase the settlement rate, while opportunistic behaviors that primarily increase the accused infringer's losses if the patent holder wins in court tend to decrease the settlement rate. The model also predicts that the effect of conduct designed to increase the accused infringer's costs of litigation is smaller for SEP than NSEP assertions. In contrast, the comparison between SEP and NSEP assertions in case of conduct that increases the accused infringer's losses yields ambiguous results. Our empirical analysis of settlement supports these theoretical predictions. We find evidence of a positive association between opportunistic conduct aimed at increasing a licensee's

\footnotetext{
${ }^{9}$ Our measures capture more than direct evidence of plainly unlawful or unethical conduct, and we do not claim that the presence of any measure constitutes, in itself, empirical proof of hold-up. We eplain this in more detail in Section 3 .
} 
cost and settlement. As predicted by theory, this association is smaller for SEPs than NSEPs. In contrast, hold-up aimed at increasing a licensor's potential recovery is negatively associated with settlement. Inline with our ambiguous theoretical prediction, we find no significant difference between SEP and NSEP assertions in the association between conduct aimed at increasing a licensee's potential loss and settlement.

\section{Technology Standards and Patents}

A technology standard defines a common set of rules or guidelines-typically selected by a group of companies working together, voluntarily, under the auspices of an SSOto foster interoperability among products in a particular domain. In the context of networking, for example, communications standards such as WiFi, Bluetooth, and LTE have in recent years been widely adopted across the globe to connect computers, smartphones, and a growing list of other devices to both one another and an ever-changing variety of related peripherals, equipment, and services.

\subsection{FRAND Licensing}

While interoperability has many beneficial (and pro-competitive) effects, competition concerns nonetheless arise when standards are protected by intellectual property rights. When competitors come together to collaborate, there may be a temptation to engage in exclusionary conduct, and patent rights to standardized technology may provide a convenient mechanism to exclude future market entrants and competitors that did not participate in the standard-setting process.

To assuage these concerns (and put competition authorities at ease), many SSOs require their members to both (i) publicly declare what patent rights (if any) they own that cover some aspect of the standard and (ii) commit to license those patents on "fair, reasonable, and non-discriminatory" (FRAND) terms. If the declaration requirement is observed, SSO participants can assemble standards that take licensing costs into account and can better assess the extent to which a company's support for a particular proposal is rooted in its technological superiority, rather than its ability to generate patent royalties. Likewise, if FRAND licensing commitments are honored, standards can be widely adopted, with no segment of the market excluded by virtue of a flat refusal to license or an offer to license only on terms that no reasonable competitor would accept.

However, FRAND commitments are no panacea. While outright exclusionary conduct is rarely observed, ${ }^{10}$ more subtle problems persist. One source of concern is that SEP licensing takes place only after the standard is adopted and generally only after it has been widely deployed. This sequence of events raises the possibility of hold-up because potential licensees are effectively "locked in" to using the standard-i.e., no reasonable alternatives exist. Accordingly, SEP licensors can (in theory at least) lever-

\footnotetext{
${ }^{10}$ Even when it is observed, courts may not recognize it as unlawful conduct, as illustrated by the recent decision in FTC v. Qualcomm, Inc. (9th Cir. 2020).
} 
age the value of standardization itself to extract royalties from licensees that exceed the incremental pre-standardization value of the patented invention.

Another related concern flows from the fact that patents essential to a given standard are typically owned by many firms. As a result, potential licensees must generally negotiate and execute multiple licenses to acquire rights to use the standard free and clear. In addition to the transaction costs involved, executing multiple licenses in an environment where hold-up is possible can lead to "royalty stacking"-i.e., an accumulation of inflated royalties demanded by multiple firms (Lemley and Shapiro, 2007). Indeed, it has been alleged that some SEP holders further exacerbate this problem by intentionally divesting assets to multiple "privateer" firms that can, collectively, extract a larger aggregate royalty than one firm licensing one unified portfolio of SEPs (Rubinfeld, 2018).

On the other hand, FRAND commitments limit an SEP licensor's ability to enforce their patent rights, which can provide incentives for potential licensees to hold out-i.e., to refuse to license SEPs or unreasonably delay in doing so (Heiden and Petit, 2017). Since the SEP licensor has already incurred sunk investment in the technology standard, in this context it is the SEP licensor that is exposed to hold-up by the potential licensee (indeed, holdout is also sometimes referred to as "reverse hold-up"). While potential licensees' ability to holdout is itself an important and related topic, in this study we observe only the actions of SEP licensors and thus, by necessity, focus on behaviors associated with hold-up.

\subsection{SEP hold-up vs. Economic hold-up}

In contrast to how the term is commonly used in the context of SEP licensing, the economic literature has traditionally taken a narrow view of what constitutes hold-up. The standard economic definition refers to a situation where: (i) two parties come to an incomplete agreement about a future transaction, (ii) one party makes irreversible relationship-specific investments in anticipation of the transaction's consummation, and (iii) the other party unexpectedly attempts to extract quasi-rents from the transaction by opportunistically exploiting the first party's earlier investment (Williamson, 1975, 1976). SEP licensing activities arguably fail to meet this definition because there is commonly neither an ex ante agreement between the parties ${ }^{11}$ nor an ex post surprise (except for rare instances of "patent ambush" ${ }^{12}$ ).

However, in the law and economics literature, hold-up has been used more expansively to encompass a variety of behaviors by which patentees may be able to extract "unreasonably high royalties" by leveraging the fact that the accused infringer or potential licensee has made investments that cannot (easily) be "redeployed to non-infringing products" (Shapiro and Lemley, 2020). While broader, this definition nonetheless tracks the general economic definition of hold-up, in that once a party has made relationship specific investments, the other party can extract a higher price than it could

\footnotetext{
${ }^{11}$ At best, the potential licensee is a third-party beneficiary of the original SEP owner's FRAND commitment to the SSO.

${ }^{12}$ See, e.g., Rambus, Inc. v. FTC, 522 F.3d 456 (D.C. Cir. 2008).
} 
have before (regardless of the existence of a specific ex ante agreement). However, this does not imply that "[ $\mathrm{t}]$ he proof that patent hold-up has occurred is simply that a patent holder demands royalties from an unhappy licensee who made a relation-specific investment" (Galetovic and Haber, 2017, p. 24). Properly defined, hold-up in the SEP context still requires that SEP enforcers engage in opportunistic conduct after potential licensees have made specific, sunk investments (Cotter et al., 2019).

In the specific context of SEP licensing, the main argument in the literature for the existence of hold-up is that SEP owners have more post-standardization bargaining power (relative to similarly situated non-SEP owners) because there are usually no adequate substitutes for the standard. As a result, the SEP owner can charge royalties in excess of the economic value of the patented technology, which can have two negative effects. First, some accused infringers and prospective licensees will accept excessive royalty rates and either pass on the increased cost to consumers or see profit margins reduced. And second, companies that anticipate hold-up will proactively avoid ite.g., by abandoning or avoiding standard-compliant product markets-which implies less technology adoption, lower output, and ultimately less innovation. The literature has additionally identified a number of different behaviors that can result in hold-up, a fact that we explore in greater detail in the section below.

However, despite the clear theoretical appeal of hold-up, empirically demonstrating its existence has proven challenging. One source of difficulty is the fact (already mentioned above) that, if companies understand the risk of hold-up, they will avoid or mitigate it. In addition, directly measuring hold-up (to the extent that it cannot be avoided) requires a comparison between the (typically confidential) royalty rate demanded by the SEP owner and the (often practically incalculable) royalty rate that would prevail in the absence of hold-up. Moreover, while there have been much-discussed instances in which individual SEP owners clearly attempted hold-up-most notably cases involving "patent ambush" or in which SEP owners preemptively sought injunctive relief before trying to negotiate a license $e^{13}$-the facts of individual cases cannot, standing alone, prove that hold-up is a systemic problem.

\section{Measuring hold-up}

In the existing literature and case law, a wide variety of behaviors have been associated with potential hold-up. Combining this existing evidence with information gleaned from court records (as detailed below), we construct a variety of measures of hold-up, which we refer to as opportunistic conduct by licensors. Table 1 provides an overview (for more details on the data collection see Online Appendix A). We group these measures into four broad types of opportunistic conduct: (1) behavior that puts pressure on prospective licensees by increasing their (broadly defined) cost of litigation, (2) measures aimed at increasing the prospective licensee's monetary loss in case the patent

\footnotetext{
${ }^{13}$ See, e.g., Realtek Semiconductor Corp. v. LSI Corp., 946 F. Supp. 2d 998 (N.D. Cal. 2013) ("[T]he court holds that defendants breached their contractual obligations to IEEE and to Realtek as a thirdparty beneficiary of that contract by seeking injunctive relief against Realtek before offering Realtek a license.").
} 
enforcer prevails in the dispute, (3) injunction requests, and (4) SEP-specific conduct related to the SEP licensor's FRAND commitment. While these behaviors have all been associated with hold-up, we stress at the outset that many are not per se unlawful and none are, standing alone, conclusive proof of hold-up. Nonetheless, measuring the frequency with which these behaviors occur (actually or allegedly) in litigation can shed light on the prevalence with which hold-up occurs.

\subsection{Licensee's litigation costs}

We begin with measures capturing conduct that increases a licensor's leverage over a potential licensee primarily by increasing the licensee's costs of mounting a defense. First, a patent enforcer may file a parallel, overlapping complaint with the U.S. International Trade Commission (ITC) requesting that the accused infringer's products be excluded from importation into the U.S. because they infringe the same patent rights asserted in court. If a patent holder initiates an ITC investigation in parallel with a district court case, we refer to this as parallel ITC litigation. Similarly, a patent holder may additionally pursue parallel litigation filed in the courts of another country. Particularly if the parties' dispute arises from negotiation of a global license, concurrent litigation in a major foreign market can affect licensing negotiations in the U.S. ${ }^{14}$ We refer to this measure as relevant litigation abroad. Moreover, licensors can increase pressure and potential costs of litigation by threatening to sue the customers of a potential licensee that has not accepted a licensing demand. We refer to this as threats to sue customers.

\subsection{Licensee's potential loss}

Next, we construct a set of measures that capture conduct that may allow licensors to increase their potential monetary recovery in court by increasing the licensee's potential loss. First, licensors can take strategic advantage of the lack of complete vertical integration among technology firms. Because technology implementation is typically carried out by a component (such as a chipset or module) that is incorporated into a larger end product, patents (if valid) are commonly infringed by multiple firms along the supply chain. This fact opens the door for a number of related opportunistic behaviors. For one, patent licensors can strategically elect to sue (or target for license demands) downstream firms. Relative to upstream component manufacturers, downstream firms generally sell larger products at higher price points and, moreover, are often disadvantaged due to a lack of familiarity with the technical details of the component that reads on the allegedly infringed patent. While in theory the same royalty can be calculated by applying both a relatively small rate to a relatively large base and

\footnotetext{
${ }^{14}$ See Microsoft Corp. v. Motorola, Inc., 696 F.3d 872, 886 (9th Cir. 2012) (holding that the district court did not abuse its discretion in concluding that Motorola's parallel SEP suit in Germany was "vexatious and oppressive" because the foreign suit was "designed to harass Microsoft with the threat of an injunction removing its products from a significant European market and so to interfere with the court's ability to decide the contractual questions already properly before it"); 795 F.3d 1024, 1032 (9th Cir. 2015) (noting that Motorola's "German action was particularly threatening to Microsoft, as its European distribution center for all Windows and Xbox products was in Germany").
} 
a relatively large rate to a relatively small base, patent owners in practice are likely to recover more in damages when they sue firms that sell end products. ${ }^{15}$ In response to this concern and in recognition of the long-standing requirement that patent damages be properly "apportioned" to cover only the patented technology at issue in the case, ${ }^{16}$ U.S. courts have ruled that reasonable royalty damages should ordinarily be calculated using the "smallest salable patent-practicing unit" (SSPPU) in an accused multi-component product as the royalty base, rather than the price of the end product under the so-called "entire market value rule" (EMVR) ${ }^{17}$ Nonetheless, this general rule has many exceptions, including when the patentee has a history of negotiating and executing licenses based on the sales price of end products. ${ }^{18}$ We capture situations where the patent enforcer bases its royalty calculations on the EMVR instead of the SSPPU in a measure called EMVR vs. SSPPU.

In addition to strategically targeting downstream firms that earn the most revenue, licensors can make licensing demands from companies at multiple levels of the supply chain. While in principle patent rights are said to "exhaust" once one level of the supply chain is licensed, ${ }^{19}$ licensors with large portfolios and complex, confidential licensing histories can attempt to "double dip" by seeking overlapping royalties from firms at different levels of the supply chain. We capture this type of behavior in a measure referred to as exhaustion.

Finally, licensors may take strategic advantage of the lack of a (thick) market for pricing licenses and any resulting information asymmetries that cut in their favor. For example, in negotiations or litigation, licensors may selectively reveal prior licenses that support what, in reality, is a relatively high royalty demand. While it is a common practice in litigation to reference existing "comparable" licenses in calculating a reasonable royalty, the extent to which any given license is truly "comparable" is often controversial due to differences in patents covered, the duration of the agreement, geographic coverage, licensee type, etc. This provides the opportunity for the patent enforcer to rely on existing licensing agreements that result in more favorable royalty calculations than what would result from accounting for any relevant differences in the technology use. We capture this type of behavior in our prior licenses not comparable measure. Relatedly, licensors may simply refuse to disclose any information justifying the requested royalty payment (or place conditions on the receipt of such information

\footnotetext{
${ }^{15}$ See Chao (2012) at pp. 119-25, 134-38 for a summary of the relevant literature. See also LaserDynamics, Inc. v. Quanta Comp., Inc., 694 F.3d 51, 68 (Fed. Cir. 2012) ("Admission of ... overall revenues, which have no demonstrated correlation to the value of the patented feature alone, only serve to make a patentee's proffered damages amount appear modest by comparison, and to artificially inflate the jury's damages calculation beyond that which is 'adequate to compensate for the infringement."').

${ }^{16}$ See Garretson v. Clark, 111 U.S. 120, 121 (1884) ("The patentee ...must in every case give evidence tending to separate or apportion ... the patentee's damages between the patented feature and the unpatented features.").

${ }^{17}$ See, e.g., VirnetX, Inc. v. Apple Inc., 767 F.3d 1308 (Fed. Cir. 2014); LaserDynamics, 694 F.3d at 67 (" $[\mathrm{I}] \mathrm{t}$ is generally required that royalties be based not on the entire product, but instead on the 'smallest salable patent-practicing unit."')

${ }^{18}$ CSIRO v. Cisco Sys., Inc., 809 F.3d 1295, 1301-04 (Fed. Cir. 2015); Ericsson, Inc. v. D-Link Sys., 773 F.3d 1201, 1225-29 (Fed. Cir. 2014).

${ }^{19}$ See Impression Prods., Inc. v. Lexmark Int'l, Inc., 137 S.Ct. 1523 (2017).
} 
that no reasonable licensee would accept). This situation is captured by our no disclosure measure.

\subsection{Injunction}

A sizeable theoretical literature explores the effect of injunctions on incentives to settle patent cases and license patent rights (e.g. Shapiro, 2010). In principle, despite committing to license SEPs on FRAND terms, SEP holders may nonetheless pursue (or threaten to pursue) injunctive relief, just as they would if asserting non-essential patents. However, in practice, injunctive relief may be more difficult to obtain for FRAND encumbered SEPs (Sidak, 2018). In a 2013 joint policy statement, the U.S. Department of Justice (DOJ) and USPTO stated expressly that in the FRAND context an injunction "may be inconsistent with the public interest." SSOs have also imposed certain limits on the availability of injunctive relief under the FRAND framework. For example, the 2015 IEEE Patent Policy significantly limited SEP licensors' ability to seek injunctive relief. Requests for injunctive relief are also subject to particular scrutiny by the courts in SEP litigation ${ }^{20}$ As such, injunctions are different from other types of opportunistic conduct. We therefore capture patent enforcers' assertion of entitlement to an injunction in a separate measure referred to as injunction.

\subsection{SEP-specific measures}

Finally, we construct a set of measures of opportunistic conduct that are unique to SEP licensing and hence for which there is no counterpart in NSEP disputes.

As noted above, an SEP holder has an incentive before a standard is finalized to declare as few patents as it plausibly can. All else equal, a technology is more likely to be incorporated into the standard if it is covered by fewer patents. Moreover, a company's advocacy for the adoption of a particular technology is, all else equal, more likely to be persuasive if the company holds few (or no) patent rights covering that technology. However, once a standard is finalized, incentives change. Now, an SEP holder has an incentive to aggressively pursue and declare as essential as many patents as possible in hopes of inflating its share of the future stream of royalties. ${ }^{21}$ In the analysis below, we refer to these two opportunistic behaviors as untimely declaration and overdeclaration, respectively.

Post-standardization, SEP licensors also may push or exceed the boundaries of their FRAND commitments. While FRAND is designed to ensure that licenses are widely available on a "non-discriminatory" basis, SEP licensors naturally face strong incentives

\footnotetext{
${ }^{20}$ The DOJ stated in its 2015 business review letter that in U.S. courts it was "unlikely that a patent holder bound by a RAND commitment, even one that does not address explicitly the availability of injunctive relief, can secure an injunction (in addition to monetary damages) in an infringement action."

${ }^{21}$ In a "top-down" approach to calculating royalties, the share of SEPs of a given standard held by a company affects directly the amount of royalties received. Moreover, Righi and Simcoe (2020) find that a majority of SEPs issue from continuation applications filed after standard publication and, "[c]onsistent with opportunistic behavior by patentees," additionally observe a large increase in SEP continuations immediately after standards are finalized.
} 
to engage in discriminatory or exclusionary licensing and, moreover, can generally do so while maintaining a facially neutral licensing policy. For example, a consistent royalty rate applied to each standard-compliant product can lead to royalties that vary greatly among companies and that capture value attributable to features and components completely unrelated to the standard. Even with a flat dollar-value-per-unit royalty, it is possible for an SEP holder to select a rate that it knows some competitors cannot afford to pay. We refer to both practices as discriminatory licensing.

Table 1: Overview of measures of opportunistic behavior

\begin{tabular}{|c|c|}
\hline Opportunistic behavior & Description \\
\hline Any opportunistic behavior & $\begin{array}{l}\text { Did the accused infringer (specifically) allege that the patent enforcer (or its prede- } \\
\text { cessor) engaged in any of the opportunistic behaviors listed below? }\end{array}$ \\
\hline \multicolumn{2}{|l|}{ Licensee's costs } \\
\hline Threats to sue customers & $\begin{array}{l}\text { Did the patent enforcer bring the accused infringer's customers into the licensing dis- } \\
\text { pute, either by contacting them, threatening to sue them, or actually suing them? }\end{array}$ \\
\hline Parallel ITC litigation & $\begin{array}{l}\text { Did the patent enforcer initiate an investigation against the accused infringer at the } \\
\text { ITC in parallel to the district court litigation? }\end{array}$ \\
\hline Relevant litigation abroad & $\begin{array}{l}\text { Did the patent enforcer seek injunctive relief against the accused infringer in related } \\
\text { litigation filed outside the U.S. (e.g., in Germany)? }\end{array}$ \\
\hline \multicolumn{2}{|l|}{ Licensee's potential loss } \\
\hline Exhaustion & $\begin{array}{l}\text { Did the accused infringer (specifically) allege that the patent was already licensed } \\
\text { (e.g., by an upstream component supplier)? }\end{array}$ \\
\hline No disclosure & $\begin{array}{l}\text { Did the accused infringer make a specific allegation that the patent enforcer simply } \\
\text { refused to disclose the terms of prior licenses with similarly situated companies? }\end{array}$ \\
\hline EMVR vs. SSPPU & $\begin{array}{l}\text { Did the accused infringer argue that the patent enforcer improperly attempted to base } \\
\text { the royalty owed on the price of the end product (using the EMVR), rather than the } \\
\text { price of a component/module (the SSPPU). }\end{array}$ \\
\hline Prior licenses not comparable & $\begin{array}{l}\text { Did the accused infringer argue that the patent enforcer improperly attempted to base } \\
\text { the royalty owed on prior licenses that were not reasonably comparable (due to dif- } \\
\text { ferences in patents, duration, geographic scope, licensee type, etc). }\end{array}$ \\
\hline \multicolumn{2}{|l|}{ Injunction } \\
\hline Injunction & $\begin{array}{l}\text { In the complaint (or counterclaim) did the patent enforcer expressly request an in- } \\
\text { junction? }\end{array}$ \\
\hline \multicolumn{2}{|l|}{ SEP-specific } \\
\hline Untimely declaration & $\begin{array}{l}\text { Did the accused infringer argue that the patent enforcer (or its predecessor) did not } \\
\text { disclose the SEP to the SSO until after the standard was adopted? }\end{array}$ \\
\hline Overdeclaration & $\begin{array}{l}\text { Did the accused infringer (specifically) allege that the patent enforcer required li- } \\
\text { censees of relevant SEPs to additionally pay royalties for rights to patents that were } \\
\text { either not essential to the relevant standardized technology generally or not relevant } \\
\text { to the accused infringer's specific products? }\end{array}$ \\
\hline Discriminatory license & $\begin{array}{l}\text { Did the accused infringer make a specific allegation that the patent enforcer adopted } \\
\text { discriminatory or exclusionary licensing terms or practices? }\end{array}$ \\
\hline
\end{tabular}




\section{Theoretical model}

In addition to providing descriptive evidence on the occurrence of opportunistic conduct, the main goal of our empirical analysis is to examine the effect of opportunistic conduct on settlement. In this section, we construct a simple model of patent litigation in order to explore how different opportunistic behaviors affect settlement.

In our model, a patent enforcer making a settlement demand to an accused infringer faces a tradeoff between a high settlement amount and a high probability that the demand be accepted. Our main result is that opportunistic behavior by the patent enforcer may tilt this tradeoff in one direction or the other. Specifically, we find that behaviors that primarily increase the accused infringer's litigation costs tend to increase the settlement rate, while behaviors that primarily increase the accused infringer's loss in case settlement fails and the patent enforcer prevails in court tend to decrease the settlement rate. Our model also allows us to study how the magnitude of these effects depends on whether the patent is standard-essential or not. We first describe our setting and compute the relevant equilibrium variables and then analyze the impact of opportunistic conduct on the settlement rate.

Setting. Consider a patent enforcer (plaintiff) $P$ and an accused infringer (defendant) $D$. Denote $c_{P}$ and $c_{D}$ the litigation costs of the patent enforcer and the accused infringer, respectively, $\theta$ the probability that the court finds that the patent is infringed, and $\alpha$ the probability that the patent's validity is upheld by the court. If the court finds that the patent is invalid, the patent enforcer incurs a loss $l_{P}{ }^{22}$ If the court finds that the patent is valid and infringed, the accused infringer incurs a loss $l_{D}$. We assume that the patent enforcer's gain if the patent is found valid and infringed is also equal to $l_{D}$. This is for instance the case if $l_{D}$ is the amount of damages paid by the accused infringer to the patent enforcer. If the court finds that the patent is valid but not infringed, we assume that neither the accused infringer nor the patent enforcer are affected by this decision. The probability of infringement $\theta \in(\underline{\theta}, \bar{\theta}]$ is known to the accused infringer while the patent enforcer only knows that it is drawn from a uniform distribution over an interval $[\underline{\theta}, \bar{\theta}]$.

Consider the following game:

- Stage 1: $P$ makes a take-it-or-leave-it settlement demand to $D$.

- Stage 2: $D$ decides whether to accept the demand. If it is accepted, the game ends; otherwise $P$ and $D$ incur litigation costs $c_{P}$ and $c_{D}$, and court decisions regarding infringement, and validity are handed down. ${ }^{23}$

Note that we implicitly assume that the patent enforcer's litigation threat is always credible, ${ }^{24}$ which is standard in the economic literature on settlement.

\footnotetext{
${ }^{22}$ For instance, the patent enforcer may incur losses because the current licensees may stop paying license fees.

${ }^{23}$ We assume that the accused infringer challenges the patent's validity, which is typically the case in practice.

${ }^{24}$ This holds if $\underline{\theta} \geq \frac{c_{P}+(1-\alpha) l_{D}}{\alpha l_{D}}$.

${ }^{25}$ For a survey see for example Spier (2007). A notable exception is Nalebuff (1987).
} 
Accused infringer's decision. The accused infringer accepts to pay a settlement amount $S$ if and only if

$$
S \leq \alpha \theta l_{D}+c_{D}
$$

or, equivalently, if and only if

$$
\theta \geq \tilde{\theta}(S) \equiv \frac{s-c_{D}}{\alpha l_{D}}
$$

As expected, the higher the settlement amount, the lower the probability that the settlement demand is accepted by the accused infringer.

Patent enforcer's decision. The patent enforcer knows that a demand $S$ will be accepted by the accused infringer with probability $\frac{\bar{\theta}-\tilde{\theta}(S)}{\bar{\theta}-\underline{\theta}}$ and turned down with probability $\frac{\tilde{\theta}(S)-\underline{\theta}}{\bar{\theta}-\underline{\theta}}$. In the latter scenario, the patent enforcer's probability of winning (i.e., the probability that the patent is found valid and infringed) is $\alpha \frac{\tilde{\theta}(S)+\underline{\theta}}{2}$. Thus, the patent enforcer's expected payoff is given by

$$
G(S)=\frac{\bar{\theta}-\tilde{\theta}(S)}{\bar{\theta}-\underline{\theta}} S+\frac{\tilde{\theta}(S)-\underline{\theta}}{\bar{\theta}-\underline{\theta}}\left[-c_{P}+\alpha l_{D} \frac{\tilde{\theta}(S)+\underline{\theta}}{2}-(1-\alpha) l_{P}\right] .
$$

The first-order condition with respect to $S$ gives the equilibrium settlement amount:

$$
S^{*}=\alpha l_{D} \bar{\theta}-c_{P}-(1-\alpha) l_{P}
$$

assuming that the parameters are such that this amount is positive. We find that $S^{*}$ increases with $l_{D}$ and $\alpha$ and decreases with $c_{P}$ and $l_{P}$, which is consistent with the intuition that the settlement amount should increase if the patent enforcer's (resp., accused infringer's) payoff absent settlement increases (resp., decreases).

Settlement rate. Denoting $\theta^{*}=\tilde{\theta}\left(S^{*}\right)$, we have

$$
\theta^{*}=\bar{\theta}-\frac{c_{P}+c_{D}+(1-\alpha) l_{P}}{\alpha l_{D}},
$$

assuming that the parameters are such that $\theta^{*} \in(\underline{\theta}, \bar{\theta}]$. We can now compute the equilibrium settlement rate, i.e., the probability that the equilibrium settlement demand is accepted:

$$
r^{*}=\frac{\bar{\theta}-\theta^{*}}{\bar{\theta}-\underline{\theta}}=\frac{1}{\bar{\theta}-\underline{\theta}} \frac{c_{P}+c_{D}+(1-\alpha) l_{P}}{\alpha l_{D}}=\frac{1}{\bar{\theta}-\underline{\theta}} \frac{\Delta}{A}
$$

where $\Delta \equiv c_{P}+c_{D}+(1-\alpha) l_{P}$ is the joint surplus generated by settlement, and $A \equiv \alpha l_{D}$ is a measure of the extent of adverse selection: It becomes more costly for the patent enforcer to separate defendant types when $A$ increases ${ }^{26}$ The equilibrium settlement

\footnotetext{
${ }^{26}$ To see why, notice that the informational rent that a patent enforcer leaves to defendants that have a type above the borderline type $\tilde{\theta}(S)$ is $\alpha \theta l_{D}+c_{D}-S=\theta A+c_{D}-S$, which is increasing in $A$.
} 
rate is higher when the joint surplus from settlement is higher and is lower when the adverse selection problem faced by the patent enforcer is more severe.

Impact of opportunistic conduct on the settlement rate. As discussed above in Section 3, a patent enforcer can rely on a variety of opportunistic conduct to place pressure on an accused infringer. In our simple framework, such conduct would lead to an increase in the accused infringer's litigation costs $c_{D}$ and/or an increase in her loss $l_{D}$ in case settlement fails and the patent enforcer prevails in court (i.e. the patent is found valid and infringed). Therefore, it could yield an increase in the joint surplus from settlement $\Delta$ and/or an increase in the extent of adverse selection $A$. Since $\Delta$ and $A$ have opposite effects on the settlement rate, the net impact of a given opportunistic behavior is ambiguous in general. Specifically, it depends on the effect of the behavior on the ratio $\Delta / A$. In particular, our model shows that the opportunistic behaviors described in Section 3.1 that (primarily) affect the accused infringer's litigation costs have a positive effect on the settlement rate. In contrast, the opportunistic behaviors described in Section 3.2 that (primarily) affect the accused infringer's loss if settlement fails and the patent enforcer prevails in court have a negative effect on the settlement rate. We can summarize these two predictions as follows:

Prediction 1. Cost-increasing opportunistic behavior leads to an increase in the settlement rate.

Prediction 2. Loss-increasing opportunistic behavior leads to a decrease in the settlement rate.

Distinction between SEP and NSEP litigation. We distinguish between SEP litigation and NSEP litigation by assuming that the stakes are higher for the former. Specifically, we assume that the patent enforcer's loss if the patent is invalidated (i.e., $l_{P}$ ), and the accused infringer's loss if settlement fails and the patent enforcer prevails in court (i.e., $l_{D}$ ) are both higher in the case of SEP litigation. ${ }^{27}$ To compare the magnitude of the effect of cost-increasing opportunistic conduct in the case of SEP litigation and NSEP litigation, we need to determine how $\partial r^{*} / \partial c_{D}$ depends on $l_{P}$ and $l_{D}$. It turns out that $\partial r^{*} / \partial c_{D}$ decreases with $l_{D}$ but does not depend on $l_{P}$. This implies that the (positive) effect of cost-increasing opportunistic behavior is smaller in the case of SEP litigation (see Prediction 3). Let us now turn to loss-increasing opportunistic conduct. It is straightforward to see that $\partial r^{*} / \partial l_{D}$ decreases with $l_{P}$ but increases with $l_{D}$. This implies that the comparison of the (negative) effect of a loss-increasing opportunistic behavior in the case of SEP litigation and NSEP litigation is ambiguous in general (see Prediction 4). We summarize the two corresponding predictions as follows:

Prediction 3. The effect of cost-increasing opportunistic behavior on the settlement rate is smaller in the case of an SEP than in the case of a NSEP.

Prediction 4. The effect of loss-increasing opportunistic behavior on the settlement rate depends ambiguously on whether the patent is an SEP or not.

\footnotetext{
${ }^{27}$ Recall that $l_{D}$ is also the patent enforcer's recovery if settlement fails and the patent is held valid and infringed.
} 


\section{Data}

\subsection{Standards and SEPs}

To identify SEPs, we utilized the Searle Center Database on Technology Standards and Standard Setting Organizations, which includes 139,620 patents declared essential to one or more standards developed by 16 SSOs and patent pools, including ETSI, IEEE, and ITU (Baron and Spulber, 2018; Baron and Pohlmann, 2018). In addition, because the declaration of a single patent is generally regarded as a declaration of the patent's entire family, ${ }_{2}^{28}$ we identified all family members of the specific patents included in the Searle database using EPO's Patstat database (version September 2019) ${ }^{29}$ and added to our data all such patents that were not already included.

\subsection{Litigation Data}

To identify all U.S. patent suits involving SEPs, we first extracted from the MaxVal Patent Litigation Databank ${ }^{30}$ basic case-level data on all patent cases filed in U.S. district courts between 2010 and 2019. We then identified all such cases in which a declared SEP or its family member was asserted or challenged ${ }^{31}$ In addition to simply matching our databases by patent number, we reviewed each match by hand to verify its accuracy ${ }^{32}$

For comparison purposes, we additionally constructed a matched sample of patent litigation involving patents that were not declared essential to a technology standard. To do so, we followed the approach used by Lemley and Simcoe (2019, p. 617) and matched each litigated SEP with a litigated NSEP (if any) that (i) was assigned the same technology classification (matched at the International Patent Classification Group level (IPC-4)), (ii) claims priority to an application filed in the same year, and (iii) was first asserted in court in the same year. We excluded from this matching process all NSEPs that were asserted alongside an SEP in the same case; thus, there is no overlap in the cases that comprise our SEP and NSEP data sets. Table A-1 in the Online Appendix show some balance tests at the patent-level. We see that most patent characteristics are uncorrelated with whether a patent is an SEP or NSEP. That said, SEPs are still correlated with patent family size and the number of inventors. These are seen as proxies for patent value, which may indicate that SEPs are on average more valuable than NSEPs in our sample, which supports our theoretical assumption about the distinction between SEP and NSEP litigation.

\footnotetext{
${ }^{28}$ ETSI's IPR FAQ, for example, instructs that "[t]he recommended practice is to declare only one member in a patent family . . . and let the system expand automatically as new members appear under this patent family."

${ }^{29}$ We use the DOCDB family definition.

${ }^{30}$ https://www.maxval.com/litigation-databank/

${ }^{31}$ Accordingly, our data does not include cases enforcing "undeclared" standard essential patents-that is, patents that were not declared to the SSO but nonetheless were alleged by their current owner to be infringed by the standard.

${ }^{32}$ In the process, we dropped a number of erroneous matches caused by inaccuracies among Chinese patent numbers included in the Searle database.
} 
Next, we conducted an in depth analysis of each case. To do this, we reviewed each case's docket, including all pleadings filed in the case, all motions filed in the case, ${ }^{33}$ court rulings on those motions, trial verdicts, and post-trial motions practice ${ }^{34}$

During this review, we identified all parties to each case and confirmed which party or parties were enforcing (or attempting to license) each patent and which party or parties were accused of infringing each patent (or seeking a declaration of non-infringement or invalidity). Further, we determined how and when each patent-party infringement allegation was resolved, and additionally made note of all substantive rulings (whether dispositive or not) concerning each patent-party pair. In addition, we identified all cases that were created by virtue of a prior case's transfer or the severance of patents or parties from a prior case. We further identified all cases that were dismissed and subsequently re-filed in substantially identical form or merged into another case. Accordingly, our data allows us to follow each patent-party pair across multiple "cases" (i.e., unique case numbers) and identify the initial filing date, final termination type and date, and all other relevant data aggregated across all intervening case dockets.

\subsection{Party, Technology, and Product Data}

We established the size of plaintiffs and defendants and categorized them into different size groups. We also identified the relationship between each set of litigants, as well as the technology and product(s) or service(s) at issue in each patent-party-level infringement allegation. Using the Stanford NPE database we categorized each patent enforcer as an operating technology company (i.e., a "practicing entity" (PE)) or a "nonpracticing entity" (NPEs) ${ }^{35}$ For each operating technology company, we further classified its relationship to the accused infringer as one of the following: (i) direct product market competitor, (ii) upstream of the accused infringer, (iii) downstream of the accused infringer, or (iv) participant in a different product market. We also recorded whether court filings indicated that the litigants had previously been parties to a licensing agreement.

For each patent-party pair, we also determined whether the accused infringer was alleged to have sold the technology in a product or service or whether instead the accused infringer was alleged to have used the technology in a context substantially unrelated to its core products or services (e.g., if infringement was limited to a non-tech company's website or advertisements). For each patent-party pair where the accused infringer was alleged to have sold the technology, we classified the accused infringer's product(s) or service(s) and made note of whether the infringing technology was substantially confined to a component of each product or whether instead each product was, itself, a component (such as a chip, chipset, or module) designed to implement the infringing technology.

\footnotetext{
${ }^{33}$ Including all motions to dismiss, motions for summary judgment, motions concerning expert witness reports or testimony, and all pre-trial reports and motions in limine.

${ }^{34}$ However, we did not collect data on appeals.

${ }^{35}$ https://npe.law.stanford.edu/
} 


\section{Results}

\subsection{Evidence of opportunistic conduct}

Table 2 shows the share of SEP and NSEP cases (defined at the patent-party level) where we found opportunistic conduct for each of the opportunistic behaviors described above in Section 3 ,

The first row in Table 2 shows our summary measure any opportunistic behavior. This variable is equal to one if any of the measures of opportunistic behavior applies. Notably, for SEP cases, this includes SEP-specific opportunistic conduct. We see that in $77 \%$ of SEP cases, at least one type of opportunistic behavior is observed or alleged. We observe at least one type of opportunistic conduct in $65 \%$ of NSEP cases. While the difference is statistically significant at $1 \%$, it is somewhat difficult to interpret its magnitude as these summary statistics mask substantial heterogeneity across different types of opportunistic conduct.

Looking at the different categories of opportunistic behavior, we see that conduct to increase a licensee's litigation costs is not all that common. Among SEP and NSEP cases, we observe that type of hold-up behavior in only $8 \%$ and $6 \%$ of cases, respectively (a difference that is also only marginally statistically significant). We see that the most common conduct takes the form of parallel ITC proceedings (5\% among SEP cases and $4 \%$ among NSEP cases). This captures a way of putting pressure on accused infringers by pursuing them in more than one venue. Similarly, licensors can pursue parallel litigation in the courts of one or more additional countries (e.g., UK or Germany). However, Table 2 reveals that litigation abroad is very rarely referenced in both U.S. SEP and NSEP cases. ${ }^{36}$ Table 2 also indicates that pressuring licensees by threatening to sue their customers is a relatively rare move that was alleged in only around $2 \%$ of cases regardless of whether they involved SEPs or NSEPs.

Next, Table 2 shows that conduct aimed at increasing the accused infringer's potential loss is much more common, in particular among SEP cases. We observe such behavior in nearly $35 \%$ of SEP cases, but only in slightly more than $10 \%$ of NSEP cases - with the difference statistically significant at $1 \%$. Looking at the individual measures, we see that exhaustion is specifically pled in around 24\% of SEP court cases compared to less than 7\% of NSEP cases. The no disclosure measure captures situations where the infringer indicated that the licensor refused to disclose the terms of prior licenses with similarly situated companies. It turns out that this is not a common occurrence, with only around 1\% of SEP and NSEP cases alleging this conduct by SEP licensors. The next two measures of opportunistic litigation behavior capture issues more directly related to the calculation of a royalty rate, which is often at the core of the parties' dispute. The EMVR vs. SSPPU variable captures situations where the accused infringer argued that the licensor improperly attempted to base the royalty owed on the price of the end product (using the EMVR), rather than the price of the standard-compliant component

\footnotetext{
${ }^{36}$ Note that, as explained in greater detail in Online Appendix A. we only take into account litigation in foreign jurisdictions if an accused infringer expressly referenced that action in the course of U.S. litigation as a potential form of misconduct or FRAND violation. Consequently, we most likely under-count relevant litigation abroad.
} 
Table 2: Opportunistic behavior by patent enforcer by SEP status

\begin{tabular}{clccc}
\hline & Opportunistic behavior & SEP & NSEP & Diff. \\
\hline & & $(1)$ & $(2)$ & $(3)$ \\
\hline 1 & Any opportunistic behavior & 77.09 & 65.47 & $11.62^{* * *}$ \\
\hline 2 & Licensee's costs & 8.01 & 6.29 & $1.72^{*}$ \\
\cline { 2 - 5 } 2.1 & Threats to sue customers & 1.64 & 2.04 & -0.40 \\
2.2 & Parallel ITC litigation & 5.11 & 3.99 & 1.11 \\
2.3 & Relevant litigation abroad & 1.32 & 0.25 & $1.06^{* * *}$ \\
\hline 3 & Licensee's potential loss & 34.82 & 10.37 & $24.45^{* * *}$ \\
\cline { 2 - 5 } 3.1 & Exhaustion & 23.97 & 6.54 & $17.42^{* * * *}$ \\
3.2 & No disclosure & 1.07 & 1.27 & -0.20 \\
3.3 & EMVR vs. SSPPU & 13.05 & 5.18 & $7.87^{* * *}$ \\
3.4 & Prior licenses not comparable & 8.70 & 5.18 & $3.51^{* * *}$ \\
\hline 4 & Injunction & 47.19 & 61.30 & $-14.11^{* * *}$ \\
\hline 5 & SEP-specific & 29.58 & NA & \\
\cline { 2 - 5 } 5.1 & Untimely declaration & 19.43 & NA & \\
5.2 & Overdeclaration & 10.15 & NA & \\
5.3 & Discriminatory license & 9.02 & NA & \\
\hline & Total cases & 1,585 & 1,176 & \\
\hline
\end{tabular}

Notes: SEP: standard essential patent; NSEP: matched non-standard essential patent. Unit of observation at the patent-partycase level; 1) In the answer (and/or other, later filings) did the accused infringer (specifically) allege that the patent enforcer (or its predecessor) engaged in some kind of opportunistic behavior or something that might constitute a FRAND violation? 2) Licensee's litigation costs: 2.1) Did the patent enforcer bring the accused infringer's customers in the licensing dispute, either by contacting them or threatening to sue them or actually suing them? 2.2) Did the patent enforcer initiate litigation against the accused infringer at the ITC in parallel to the district court litigation?; 2.3) Did the patent enforcer initiate litigation against the accused infringer in another country - e.g., in an attempt to get an injunction in Germany when it couldn't get an injunction in the US? 3) Licensee's potential loss: 3.1) Did the accused infringer (specifically) allege that the patent was already licensed (often by an upstream component supplier)? 3.2) Did the accused infringer make a specific allegation that the patent enforcer simply refused to disclose the terms of prior licenses with similarly situated companies? 3.3) Did the accused infringer argue that the patent enforcer was improperly trying to base the royalty owed on the price of the end product (using the EMVR), rather than the price of a component/module (the SSPPU). 3.4) Did the accused infringer argue that the patent enforcer was improperly trying to base the royalty owed on prior licenses that were not really comparable (due to differences in patents, duration, geographic scope, licensee type, etc). 4) In the complaint (or counterclaim) did the patent enforcer request an injunction? 5) SEP-specific: 5.1) Did the accused infringer argue that the patent enforcer (or its predecessor) did not disclose the SEP to the SSO until after the technology was adopted? 5.2) Did the accused infringer argue that the patent enforcer was trying to force the accused infringer to license (along with SEPs) additional patents that were not actually essential to the standard? 5.3) Did the accused infringer make a specific allegation that the patent enforcer adopted discriminatory or exclusionary licensing terms or practices? 
(the SSPPU). We find that this allegation is relatively common in SEP cases, with accused infringers making this argument in around $13 \%$ of cases. With respect to NSEP assertions, this argument is made in only $5 \%$ of cases. The prior licenses not comparable measure captures cases in which the accused infringer argued that the licensor improperly attempted to calculate the royalty owed by reference to prior licensing agreements that were, in fact, not reasonably comparable due to differences in the set of licensed patents, duration, geographic scope, licensee type, etc. We observed this argument in less than $8 \%$ of SEP and 5\% of NSEP cases in our data.

When we look at requests for injunctions, we see that they are more common among NSEP than SEP cases (61\% vs. 47\%) ${ }^{37}$ However, these statistics are difficult to interpret. As discussed above in Section 3.3, because of the FRAND framework, the bar for obtaining injunctive relief is arguably higher in SEP cases. This makes it difficult to assess whether $47 \%$ among SEP cases is a large or small percentage compared to $61 \%$ among NSEP disputes.

Finally, Table 2 also shows shares for our SEP-specific measures of opportunistic conduct. We find that in nearly $30 \%$ of SEP disputes, there is some allegation of this type of opportunistic conduct. Untimely declaration is alleged in 19\% of SEP cases. SEP licensors are accused of overdeclaration, i.e., asserting declared SEPs that may in fact not be standard-essential, in $10 \%$ of cases. While this only reflects an allegation made by accused infringers, our data on dispositive case outcomes supports the veracity of these allegations. Overdeclaration was not alleged in a single case in which infringement was proven. By contrast, of all decided cases in which overdeclaration was alleged, half ended in a decision of invalidity and the other half resulted in a decision of noninfringement. Discriminatory licensing is alleged in around 9\% of cases.

In interpreting these numbers, it is important to keep in mind that disclosure of opportunistic behaviors is, to varying extents, a function of the information that litigation generates over time. For example, while an assertion of entitlement to injunctive relief is typically made (or not) in the SEP holder's initial complaint, a majority of the behaviors that we study are not revealed until the accused infringer answers the complaint, and even then often not until the accused infringer files an amended version of the answer incorporating additional details discovered in the early stages of litigation. To account for this, we separately examine the subset of cases in which the accused infringer filed at least one answer to the complaint. Reassuringly, Table A-2 in the Online Appendix shows that the shares of cases that allege opportunistic conduct do not change much (despite dropping more than half of the sample). There is, however, one notable change. Table A-2 shows that the share of disputes where conduct to increase a licensee's costs are alleged is now larger among NSEP and SEP cases. However, the difference is again small; still, in combination with the results for our full sample in Table 2, this suggests that there is no meaningful difference between SEP and NSEP disputes for this type of opportunistic conduct.

\footnotetext{
${ }^{37}$ To be clear, we refer here to specific requests for injunction relief made in pleadings-i.e., complaints and counterclaims-rather than motions for preliminary or permanent injunctions.
} 


\subsection{Determinants of opportunistic conduct}

Next, we analyze the determinants of opportunistic conduct. We estimate the likelihood that a given type of opportunistic behavior is present in a given case using a linear probability model. In Appendix $B$, we describe the variables that serve as determinants.

Table 3: Determinants of opportunistic behavior by patent enforcer

\begin{tabular}{|c|c|c|c|c|c|c|c|c|c|}
\hline \multirow[t]{2}{*}{ Outcome: } & \multicolumn{2}{|c|}{ Any } & \multicolumn{2}{|c|}{ Costs } & \multicolumn{2}{|c|}{ Loss } & \multicolumn{2}{|c|}{ Injunction } & \multirow{2}{*}{$\frac{\text { SEP-specific }}{\text { SEP }}$} \\
\hline & SEP & SEP/NSEP & SEP & SEP/NSEP & SEP & SEP/NSEP & SEP & SEP/NSEP & \\
\hline & (1) & (2) & (3) & (4) & (5) & (6) & (7) & (8) & (9) \\
\hline (1) SEP & & $\begin{array}{c}0.033 \\
(0.076)\end{array}$ & & $\begin{array}{c}-0.019 \\
(0.015)\end{array}$ & & $\begin{array}{l}0.072^{* *} \\
(0.033)\end{array}$ & & $\begin{array}{c}-0.177^{* * *} \\
(0.079)\end{array}$ & \\
\hline \multicolumn{10}{|l|}{$P / D$ characteristics } \\
\hline (2) $\mathrm{P}$ is NPE & $\begin{array}{l}-0.177^{*} \\
(0.090)\end{array}$ & $\begin{array}{c}0.163 \\
(0.118)\end{array}$ & $\begin{array}{l}-0.065 \\
(0.086)\end{array}$ & $\begin{array}{c}0.002 \\
(0.031)\end{array}$ & $\begin{array}{c}-0.097 \\
(0.131)\end{array}$ & $\begin{array}{c}0.004 \\
(0.040)\end{array}$ & $\begin{array}{c}-0.602^{* * * *} \\
(0.105)\end{array}$ & $\begin{array}{c}0.097 \\
(0.135)\end{array}$ & $\begin{array}{c}0.643^{* * *} \\
(0.095)\end{array}$ \\
\hline (3) P size & $\begin{array}{c}0.007 \\
(0.037)\end{array}$ & $\begin{array}{c}-0.043 \\
(0.029)\end{array}$ & $\begin{array}{l}-0.016 \\
(0.030)\end{array}$ & $\begin{array}{l}-0.038 \\
(0.024)\end{array}$ & $\begin{array}{c}0.185^{* * * *} \\
(0.052)\end{array}$ & $\begin{array}{l}0.048^{* * *} \\
(0.020)\end{array}$ & $\begin{array}{c}-0.063 \\
(0.048)\end{array}$ & $\begin{array}{l}-0.065^{* * *} \\
(0.032)\end{array}$ & $\begin{array}{c}0.139^{* * * *} \\
(0.043)\end{array}$ \\
\hline (4) D size & $\begin{array}{l}0.028^{*} \\
(0.016)\end{array}$ & $\begin{array}{c}0.007 \\
(0.018)\end{array}$ & $\begin{array}{c}-0.012 \\
(0.007)\end{array}$ & $\begin{array}{l}-0.003 \\
(0.004)\end{array}$ & $\begin{array}{c}0.085^{* * * *} \\
(0.013)\end{array}$ & $\begin{array}{c}0.045^{* * *} \\
(0.009)\end{array}$ & $\begin{array}{c}0.011 \\
(0.015)\end{array}$ & $\begin{array}{l}-0.002 \\
(0.019)\end{array}$ & $\begin{array}{l}0.017^{*} \\
(0.010)\end{array}$ \\
\hline (5) P is both P and D & $\begin{array}{c}-0.109 \\
(0.069)\end{array}$ & $\begin{array}{c}0.024 \\
(0.052)\end{array}$ & $\begin{array}{l}0.102^{* *} \\
(0.043)\end{array}$ & $\begin{array}{c}0.123 * * * \\
(0.047)\end{array}$ & $\begin{array}{c}0.158^{* * * *} \\
(0.050)\end{array}$ & $\begin{array}{c}0.120^{* * *} \\
(0.044)\end{array}$ & $\begin{array}{c}-0.002 \\
(0.065)\end{array}$ & $\begin{array}{c}0.063 \\
(0.053)\end{array}$ & $\begin{array}{c}-0.129^{* * *} \\
(0.057)\end{array}$ \\
\hline (6) D is both P and D & $\begin{array}{c}-0.072^{* * *} \\
(0.020)\end{array}$ & $\begin{array}{c}-0.022 \\
(0.026)\end{array}$ & $\begin{array}{c}0.109^{* * *} \\
(0.015)\end{array}$ & $\begin{array}{c}0.087^{* * *} \\
(0.014)\end{array}$ & $\begin{array}{c}0.025 \\
(0.027)\end{array}$ & $\begin{array}{c}0.027 \\
(0.022)\end{array}$ & $\begin{array}{l}0.048^{* * *} \\
(0.020)\end{array}$ & $\begin{array}{c}0.071^{* * *} \\
(0.027)\end{array}$ & $\begin{array}{c}-0.191^{* * *} \\
(0.022)\end{array}$ \\
\hline (7) P upstream of D & $\begin{array}{l}-0.033 \\
(0.054)\end{array}$ & $\begin{array}{c}0.067 \\
(0.072)\end{array}$ & $\begin{array}{c}0.014 \\
(0.065)\end{array}$ & $\begin{array}{c}0.064 \\
(0.045)\end{array}$ & $\begin{array}{c}0.143 \\
(0.099)\end{array}$ & $\begin{array}{c}0.193 * * * \\
(0.054)\end{array}$ & $\begin{array}{l}-0.017 \\
(0.084)\end{array}$ & $\begin{array}{l}0.143^{*} \\
(0.081)\end{array}$ & $\begin{array}{c}0.288^{* * * *} \\
(0.075)\end{array}$ \\
\hline (8) P and D competitors & $\begin{array}{c}-0.081 \\
(0.067)\end{array}$ & $\begin{array}{c}0.001 \\
(0.063)\end{array}$ & $\begin{array}{l}-0.021 \\
(0.058)\end{array}$ & $\begin{array}{c}0.051 \\
(0.040)\end{array}$ & $\begin{array}{l}-0.136 \\
(0.097)\end{array}$ & $\begin{array}{l}-0.061 \\
(0.051)\end{array}$ & $\begin{array}{c}-0.158^{* * *} \\
(0.079)\end{array}$ & $\begin{array}{l}-0.029 \\
(0.069)\end{array}$ & $\begin{array}{l}0.174 * * \\
(0.074)\end{array}$ \\
\hline (9) $D$ prior licensee of $P$ & $\begin{array}{c}0.244 * * * \\
(0.045)\end{array}$ & $\begin{array}{l}0.193^{* * * *} \\
(0.043)\end{array}$ & $\begin{array}{c}0.050 \\
(0.049)\end{array}$ & $\begin{array}{c}0.002 \\
(0.038)\end{array}$ & $\begin{array}{l}0.124^{* * *} \\
(0.048)\end{array}$ & $\begin{array}{c}0.123 * * * \\
(0.042)\end{array}$ & $\begin{array}{c}0.339 * * * \\
(0.048)\end{array}$ & $\begin{array}{c}0.141 * * * \\
(0.050)\end{array}$ & $\begin{array}{l}-0.090 \\
(0.054)\end{array}$ \\
\hline (10) D technology user & $\begin{array}{c}-0.255^{*} \cdots * \\
(0.074)\end{array}$ & $\begin{array}{c}0.030 \\
(0.139)\end{array}$ & $\begin{array}{c}-0.056^{* *} \\
(0.024)\end{array}$ & $\begin{array}{c}-0.047^{* * *} \\
(0.018)\end{array}$ & $\begin{array}{l}0.148^{* * *} \\
(0.065)\end{array}$ & $\begin{array}{c}0.115 \\
(0.059)\end{array}$ & $\begin{array}{c}-0.053 \\
(0.083)\end{array}$ & $\begin{array}{c}0.136 \\
(0.131)\end{array}$ & $\begin{array}{c}-0.178^{* * *} \\
(0.063)\end{array}$ \\
\hline (11) Tech. in component & $\begin{array}{c}-0.056 \\
(0.059)\end{array}$ & $\begin{array}{c}-0.181^{* * *} \\
(0.072)\end{array}$ & $\begin{array}{l}-0.001 \\
(0.043)\end{array}$ & $\begin{array}{c}0.021 \\
(0.022)\end{array}$ & $\begin{array}{c}-0.206^{* * * *} \\
(0.067)\end{array}$ & $\begin{array}{l}-0.021 \\
(0.024)\end{array}$ & $\begin{array}{l}-0.098^{*} \\
(0.054)\end{array}$ & $\begin{array}{c}-0.224^{* * * *} \\
(0.084)\end{array}$ & $\begin{array}{c}-0.038 \\
(0.051)\end{array}$ \\
\hline Case characteristics & & & & & & & & & \\
\hline (12) Declaratory action & $\begin{array}{c}0.074 \\
(0.057)\end{array}$ & $\begin{array}{c}0.026 \\
(0.056)\end{array}$ & $\begin{array}{l}0.120 * * \\
(0.058)\end{array}$ & $\begin{array}{c}0.116^{* * * *} \\
(0.043)\end{array}$ & $\begin{array}{c}-0.066 \\
(0.048)\end{array}$ & $\begin{array}{c}-0.051 \\
(0.051)\end{array}$ & $\begin{array}{c}-0.449 * * * * \\
(0.065)\end{array}$ & $\begin{array}{c}-0.379 * * * \\
(0.067)\end{array}$ & $\begin{array}{c}0.291^{* * * *} \\
(0.075)\end{array}$ \\
\hline (13) D answer count & $\begin{array}{c}0.078^{* * *} \\
(0.012)\end{array}$ & $\begin{array}{l}0.087^{* * * *} \\
(0.014)\end{array}$ & $\begin{array}{c}0.011 \\
(0.010)\end{array}$ & $\begin{array}{l}0.016^{* * *} \\
(0.008)\end{array}$ & $\begin{array}{c}0.174^{* * *} \\
(0.012)\end{array}$ & $\begin{array}{c}0.149^{* * *} \\
(0.011)\end{array}$ & $\begin{array}{l}0.027^{* * *} \\
(0.013)\end{array}$ & $\begin{array}{c}0.058^{* * * *} \\
(0.016)\end{array}$ & $\begin{array}{l}0.062^{* * * *} \\
(0.015)\end{array}$ \\
\hline (14) MTD & $\begin{array}{c}0.403^{* * *} \\
(0.037)\end{array}$ & $\begin{array}{c}0.229^{* * * *} \\
(0.055)\end{array}$ & $\begin{array}{c}0.069 \\
(0.046)\end{array}$ & $\begin{array}{c}0.024 \\
(0.028)\end{array}$ & $\begin{array}{c}0.585^{* * * *} \\
(0.089)\end{array}$ & $\begin{array}{c}0.238^{* * *} \\
(0.063)\end{array}$ & $\begin{array}{c}0.239 \\
(0.152)\end{array}$ & $\begin{array}{l}0.150^{*} \\
(0.087)\end{array}$ & $\begin{array}{l}0.156^{* * *} \\
(0.062)\end{array}$ \\
\hline (15) MSJ & $\begin{array}{c}0.126^{* * * *} \\
(0.029)\end{array}$ & $\begin{array}{c}0.137^{* * * *} \\
(0.033)\end{array}$ & $\begin{array}{c}0.008 \\
(0.026)\end{array}$ & $\begin{array}{c}0.002 \\
(0.022)\end{array}$ & $\begin{array}{c}0.001 \\
(0.035)\end{array}$ & $\begin{array}{l}0.081^{* * *} \\
(0.036)\end{array}$ & $\begin{array}{c}0.041 \\
(0.040)\end{array}$ & $\begin{array}{c}0.030 \\
(0.043)\end{array}$ & $\begin{array}{c}0.144 * * * \\
(0.043)\end{array}$ \\
\hline (16) Case consolidated & $\begin{array}{c}0.061 \\
(0.063)\end{array}$ & $\begin{array}{c}0.018 \\
(0.052)\end{array}$ & $\begin{array}{l}-0.032 \\
(0.026)\end{array}$ & $\begin{array}{l}-0.038^{*} \\
(0.019)\end{array}$ & $\begin{array}{l}0.085^{* * *} \\
(0.040)\end{array}$ & $\begin{array}{l}0.065^{* *} \\
(0.035)\end{array}$ & $\begin{array}{l}-0.140 * * \\
(0.061)\end{array}$ & $\begin{array}{c}-0.141^{* * * *} \\
(0.050)\end{array}$ & $\begin{array}{c}0.210 * * * * \\
(0.044)\end{array}$ \\
\hline Patent characteristics & & & & & & & & & \\
\hline (17) Patent reassigned & $\begin{array}{c}-0.012 \\
(0.038)\end{array}$ & $\begin{array}{c}-0.046 \\
(0.044)\end{array}$ & $\begin{array}{c}-0.098^{* *} \\
(0.038)\end{array}$ & $\begin{array}{c}-0.037 \\
(0.025)\end{array}$ & $\begin{array}{c}0.219 * * * \\
(0.028)\end{array}$ & $\begin{array}{c}0.121 * * * \\
(0.025)\end{array}$ & $\begin{array}{l}-0.047 \\
(0.041)\end{array}$ & $\begin{array}{c}-0.083 \\
(0.055)\end{array}$ & $\begin{array}{c}-0.042 \\
(0.032)\end{array}$ \\
\hline Case filing year & Yes & Yes & Yes & Yes & Yes & Yes & Yes & Yes & Yes \\
\hline $\mathrm{R}^{2}$ & 0.298 & 0.196 & 0.188 & 0.145 & 0.368 & 0.331 & 0.593 & 0.333 & 0.382 \\
\hline Observations & 1,585 & 2,761 & 1,585 & 2,761 & 1,585 & 2,761 & 1,585 & 2,761 & 1,585 \\
\hline
\end{tabular}

Notes: SEP: standard essential patent; NSEP: matched non-standard essential patent; Any: equal to one if any of the measures listed in Table 2 is equal to one; Costs: equal to one if any of the measures 2.1-2.3 listed in Table 2 is equal to one; Loss: equal to one if any of the measures 3.1-3.4 listed in Table 2 is equal to one; Injunction: equal to one if measure 4 listed in Table 2 is equal to one; SEP-specific: equal to one if any of the measures 5.1-5.3 listed in Table 2 is equal to one. Unit of observation at the patent-party-case level; * significant at $10 \%, * *$ at $5 \%, * * *$ at $1 \%$.

Table 3 shows the results for our summary measure of opportunistic behavior, as well as the different types of hold-up conduct (Table A-3 in the Online Appendix provides results when we condition our sample to at least one response by the defendant). We report results using only the set of SEP cases as well as results that rely on the comparison between SEP and NSEP cases.

Turning first to column (1), we note that opportunistic behavior, generally, is positively associated with a prior license between the parties. This suggests that in situa- 
tions where a prior agreement has broken down or is up for renewal, the SEP enforcer tends to behave more aggressively towards the accused infringer. Such cases may in fact correspond directly to the original definition of hold-up described in Section 2.2 above. We also observe a positive association between defendant size and opportunistic conduct. On the other hand, column (1) also shows that opportunistic conduct is observed less often in cases with: a plaintiff that is an NPE; an accused infringer that is both a licensor and licensee of SEPs; or an accused infringer that uses, rather than sells, the allegedly infringing technology. We also see that the coefficients on certain litigation milestones - answers by the defendant, a motion to dismiss (MTD), and a motion for summary judgement (MSJ) - are all positively associated with observing opportunistic conduct. These variables capture to a certain extent the fact that more information is revealed as a case progresses, which makes it more likely that certain conduct is brought to light. This suggests that it is important to control for these measures in our regressions. Turning next to the comparison between SEP and NSEP disputes in column (2), we first note that the SEP dummy is positive albeit statistically indistinguishable from zero. This suggests that there is no statistically significant difference in opportunistic conduct between SEP and NSEP disputes after controlling for the various litigant, case, and patent characteristics. Looking at the specific determinants, we see that very few variables are statistically significant: the positive association between a prior licensing agreement and opportunistic conduct and a negative association between infringement occurring only in a component of the accused product.

In columns (3) and (4), we look at the determinants of conduct aimed at increasing a licensee's costs. The results are substantially the same for the SEP-only and the combined SEP/NSEP samples: we see that this type of conduct is more likely in disputes where plaintiffs and defendants are both licensors and licensees in the market for technology. If the defendant merely uses the infringing technology to sell an unrelated product, we are less likely to observe this type of opportunistic conduct. In addition, the SEP dummy variable is again not statistically different from zero.

Looking at columns (5) and (6), we see that several of the variables are associated with conduct designed to increase the licensee's loss in case the licensor prevails in court. Again, we see few differences between the results for the SEP and the combined SEP/NSEP samples. Plaintiff and defendant size are both positively associated with observing conduct by the licensor aimed at increasing their monetary recovery if they prevail. Again, we find that this type of conduct is more likely in disputes that were preceded by a licensing agreement. We also highlight that in column (6), the SEP dummy is positive and statistically significant, suggesting a 7\% difference in the likelihood of observing loss-increasing opportunistic conduct among SEP cases compared NSEP cases.

In columns (7) and (8), we analyze the determinants for requests for an injunction. There are two results that stand out. First, when we focus on the SEP sample, we see that NPEs are much less likely to request an injunction. This is expected given that NPEs are relatively unlikely to obtain injunctive relief following the 2006 Supreme Court decision in eBay vs. MercExchange. ${ }^{38}$ Not surprisingly, the effect vanishes when we

\footnotetext{
${ }^{38}$ eBay Inc. v. MercExchange, L.L.C. (547 U.S. 388, 392-93 [2006]).
} 
compare SEPs to NSEPs since we observe a similar effect for NPEs among NSEP disputes. Second, the SEP dummy variable is negative and statistically significant, reflecting the lower likelihood of observing requests for injunctions among SEP than NSEP cases as shown in Table 2 above.

Finally, in column (9), we consider the determinants of SEP-specific opportunistic conduct. By definition, for this type of opportunistic conduct, we cannot carry out any comparison between SEP and NSEP assertions. That said, we see that NPEs are significantly more likely to engage in opportunistic behaviors related to SEP declarations or discriminatory licensing. Also, party size, if the plaintiff is upstream of the defendant, and if the parties are product market competitors are all positively associated with SEPspecific opportunistic conduct. In contrast, we are less likely to observe this conduct if the defendant is a technology user and if the defendant is both licensor and licensee.

\subsection{Opportunistic conduct and settlement}

Next, we analyze the impact of opportunistic behaviors on case outcomes. The small existing literature on SEP litigation has focused on the analysis of decisions on the merits (Lemley and Simcoe, 2019). Instead, following closely our theoretical model, we focus on the impact of opportunistic conduct on settlement. We focus on settlement as our measure for case outcome for at least two reasons. First, settlement is by far the most common outcome that we observe. Decisions on the merits are exceedingly rare, in our sample only slightly more then $5 \%$ of cases end with a substantive ruling (see Figure A-1 in the Online Appendix). Similarly, in the set of SEP and NSEP cases analyzed in Lemley and Simcoe (2019), only 8\% of cases ended with a decision on the merits. Second, the intended goal of most forms of opportunism that we study is arguably to induce accused infringers to accept the patent enforcer's royalty demands through a settlement agreement.

Table 4 reports our regression results. We estimate a linear probability model where the outcome is equal to one if the case settled (measured at the patent-party-case level) ${ }^{39}$ We again present results using only variation among SEP cases and results where we rely on variation between SEP and NSEP cases. All regressions include the variables included in our determinants analysis in Table 3.

We present results for the summary measure any opportunistic behavior in columns (1) and (2), and results for the two different types of opportunistic conduct analzyed in our model in the remaining columns. In column (1), we see that when we rely on only variation among SEP cases, our summary measure of hold-up is not statistically significant. In other words, there is no evidence of any association between hold-up and settlement. However, when we rely on variation between SEP and NSEP cases, we see that the interaction term any opportunistic $\times S E P$ is negative and statistically significant at 5\%. This means that SEP cases in which some form of opportunistic conduct is alleged are $12 \%$ less likely to settle relative to NSEP cases. The coefficients on the any opportunistic behavior and SEP variables on their own, in contrast, show that SEP cases

\footnotetext{
${ }^{39}$ Note that we only compare settled and decided cases, and drop all cases that were terminated on "other" grounds or remain ongoing.
} 
are more likely to settle than NSEP cases and cases where hold-up is alleged are also more likely to settle.

Next, in columns (3) and (4), we look at the association between conduct aimed at increasing the licensee's litigation costs and settlement. Here Prediction 1 suggested a positive effect of this type of conduct on settlement. Indeed, when we use only variation in opportunistic conduct among SEP cases, we see that our costs measure is positively associated with settlement (the coefficient is statistically significant at 1\%). Cases where such conduct occurs are almost 19\% more likely to settle. However, when we compare SEP and NSEP cases, the interaction term is negative (although statistically significant only at 10\%). This result is inline with Prediction 3 which suggested that the positive relation between our costs measure and settlement would be smaller for SEP than NSEP disputes.

In columns (5) and (6), we look at hold-up conduct that is likely to increase the licensee's loss if the licensor prevails in the case. In column (5), we rely only on variation among SEP cases. We find that loss-increasing conduct is negatively associated with settlement as stated by Prediction 2 . The effect is again sizeable, the coefficient suggests a $9 \%$ drop in the likelihood of settlement. Here the comparison between SEP and NSEP cases suggests no statistically significant association between this type of hold-up on settlement. Prediction 4 in fact suggested that the sign of the effect was ambiguous.

In Table A-4 in the Online Appendix, we restrict the sample again to cases with at least one answer from the defendant. The results are overall very similar to those for the full sample. However, the positive coefficient on the measure that captures costincreasing opportunistic conduct is no longer statistically significant in column (3) for the SEP-only sample.

\section{Conclusion}

We contribute to the literature on SEP licensing by quantifying the prevalence of opportunistic behaviors (or allegations thereof) revealed in the dockets of all U.S. district court cases filed 2010-2019 to enforce declared SEPs and by comparing them to court cases enforcing a matched set of NSEPs. Despite well recognized deficiencies in the empirical literature surrounding SEP hold-up, scholars have to date failed to take full advantage of information available in public filings. We aim to fill this gap in our understanding of SEP licensing.

Overall, we find evidence of opportunistic behavior by the SEP enforcer in approximately $77 \%$ of patent-party level SEP assertions compared to 65\% of NSEP assertions. However, these headline figures conceal important differences in the occurrence of different types of opportunistic conduct. Among conduct that is comparable between SEP and NSEP cases, we find the biggest difference between behaviors designed to increase the accused infringer's loss in case the patent enforcer prevails in litigation. There is significantly more opportunistic conduct of this type in SEP disputes. We also find a sizeable amount of SEP-specific opportunistic conduct, in nearly 30\% of SEP cases.

While it is true that many of our measures of opportunistic behavior are based on al- 
Table 4: Opportunistic behavior and case outcomes

\begin{tabular}{|c|c|c|c|c|c|c|}
\hline \multirow[t]{2}{*}{ Outcome: } & \multicolumn{6}{|c|}{ Settlement $(0 / 1)$} \\
\hline & SEP & SEP/NSEP & SEP & SEP/NSEP & SEP & SEP/NSEP \\
\hline & (1) & (2) & (3) & (4) & (5) & (6) \\
\hline Any opportunistic & $\begin{array}{l}-0.028 \\
(0.024)\end{array}$ & $\begin{array}{l}0.121^{* *} \\
(0.049)\end{array}$ & & & & \\
\hline Any opportunistic $\times$ SEP & & $\begin{array}{c}-0.123^{* *} \\
(0.055)\end{array}$ & & & & \\
\hline Costs & & & $\begin{array}{c}0.188 * * * \\
(0.036)\end{array}$ & $\begin{array}{c}0.255^{* * *} \\
(0.043)\end{array}$ & & \\
\hline Costs $\times$ SEP & & & & $\begin{array}{l}-0.098^{*} \\
(0.051)\end{array}$ & & \\
\hline Loss & & & & & $\begin{array}{c}-0.093^{* * *} \\
(0.027)\end{array}$ & $\begin{array}{l}-0.047 \\
(0.078)\end{array}$ \\
\hline Loss $\times$ SEP & & & & & & $\begin{array}{c}-0.004 \\
(0.082)\end{array}$ \\
\hline SEP & & $\begin{array}{c}0.138^{* * * *} \\
(0.052)\end{array}$ & & $\begin{array}{l}0.066^{* * *} \\
(0.032) \\
\end{array}$ & & $\begin{array}{l}0.061^{*} \\
(0.031)\end{array}$ \\
\hline Covariates & Yes & Yes & Yes & Yes & Yes & Yes \\
\hline Case filing year & Yes & Yes & Yes & Yes & Yes & Yes \\
\hline $\mathrm{R}^{2}$ & 0.297 & 0.218 & 0.312 & 0.227 & 0.306 & 0.211 \\
\hline Observations & 1,585 & 2,761 & 1,585 & 2,761 & 1,585 & 2,761 \\
\hline
\end{tabular}

Notes: SEP: standard essential patent; NSEP: matched non-standard essential patent. Any: equal to one if any of the measures listed in Table 2 is equal to one; Costs: equal to one if any of the measures 2.1-2.3 listed in Table 2 is equal to one; Loss: equal to one if any of the measures 3.1-3.4 listed in Table 2 is equal to one. Covariates listed in Online Appendix B Unit of observation at the patent-party-case level; * significant at $10 \%, * *$ at $5 \%,{ }^{* * *}$ at $1 \%$.

legations by accused infringers, we strictly limit our data to allegations of opportunistic conduct that are supported by specific factual statements. Moreover, by combining our measures with detailed information on litigants and case outcomes, we find support for the general veracity of accused infringers' pleadings. In addition, while we do not claim that the presence of any behavior that we observe constitutes per se empirical proof of hold-up, our examination of factors that correlate with the different opportunistic behaviors links our analysis to the theoretical literature on patent hold-up, and we note that opportunistic behaviors are likely to be particularly effective in the SEP licensing context due to a general lack of adequate substitutes to standardized technology.

Finally, we explore whether our measures of opportunistic behavior affect case outcomes in form of settlement. Interestingly, our empirical findings show that opportunistic conduct has mixed effects on settlement. We provide a theoretical explanation for these results based on the distinction between behaviors that mainly aim at increasing the accused infringer's litigation costs and those that primarily increase the accused infringer's loss in case settlement fails and the SEP owner prevails in court. While we cannot make claims about the welfare effects of opportunistic behaviors by SEP holders based on our analysis, we believe that the distinction above may also matter for those effects. 


\section{References}

Barnett, J. M. (2017). Has the Academy Led Patent Law Astray? Berkeley Technology Law Journal 32(4), 1313-1380.

Baron, J. and T. Pohlmann (2018). Mapping Standards to Patents using Declarations of Standard-Essential Patents. Journal of Economics \& Management Strategy 27, 504-534.

Baron, J. and D. F. Spulber (2018). Technology Standards and Standard Setting Organizations: Introduction to the Searle Center Database. Journal of Economics \& Management Strategy 27.

Blecker, M., T. Sanchez, and E. Stasik (2016). An Experience-Based Look At The Licensing Practices That Drive The Cellular Communications Industry: Whole Portfolio/Whole Device Licensing. Les Nouvelles, 221-233.

Chao, B. (2012). The Case for Contribution in Patent Law. University of Cincinnati Law Review 80(1), 113-159.

Contreras, J. (2019). Much Ado about Hold-up. University of Illinois Law Review 875, 875.

Contreras, J. L. (2017). Assertion of standard essential patents by non-practicing entities. In S. D. Daniel (Ed.), Patent Assertion Entities and Competition Policy. Cambridge, UK: Cambridge University Press.

Cotter, T. F., E. Hovenkamp, and N. Siebrasse (2019). Demystifying Patent Holdup. Washington \& Lee Law Review 76(4), 1501-1565.

DOJ/FTC (2007). Antitrust Enforcement and Intellectual Property Rights. Technical report, U.S. Department of Justice and Federal Trade Commission.

Epstein, R. and K. B. Noroozi (2017). Why Incentives for "Patent Holdout" Threaten to Dismantle FRAND, and Why it Matters. Berkeley Technology Law Journal 32(4), 1381-1431.

FTC (2011). The Evolving IP Marketplace: Aligning Patent Notice and Remedies with Competition. Technical report, Federal Trade Commission.

Galetovic, A. and S. Haber (2017). The Fallacies of Patent-Holdup Theory. Journal of Competition Law \& Economics 13(1), 1-44.

Galetovic, A., S. Haber, and R. Levine (2015). An Empirical Examination of Patent Hold-up. Journal of Competition Law \& Economics 11(3), 549-578.

Heiden, B. and N. Petit (2017). Patent Trespass and the Royalty Gap: Exploring the Nature and Impact of Patent Holdout. Report, 4IP Council.

Landis, R. J. and G. G. Koch (1977). The Measurement of Observer Agreement for Categorical Data. Biometrics 33(1), 159-174.

Lemley, M. (2007). Ten things to do about patent holdup of standards (and one not to). Boston College Law Review 48, 149-168.

Lemley, M. and C. Shapiro (2007). Patent Hold-Up and Royalty Stacking. Texas Law Review 85, 1991-2049. 
Lemley, M. A. and T. Simcoe (2019). How Essential are Standard-Essential Patents? Cornell Law Review 104(3), 607-642.

Love, B. J. and C. Helmers (2022). Are Market Prices for Patent Licenses Observable? Evidence from 4G and 5G Licensing. Columbia Science Technology Law Review 24, 55-101.

Nalebuff, B. (1987). Credible Pretrial Negotiation. The RAND Journal of Economics 18(2), 198210.

Righi, C. and T. Simcoe (2020). Patenting Inventions or Inventing Patents? Strategic Use of Continuations at the USPTO. Nber working paper no. 27686.

Rubinfeld, D. (2018). IP Privateering in the Markets for Desktop and Mobile Operating Systems. Berkeley Technology Law Journal 33, 85-130.

Scott Morton, F. and C. Shapiro (2016). Patent Assertions: Are We Any Closer to Aligning Reward to Contribution? In L. Josh and S. Stern (Eds.), Innovation Policy and the Economy. Univ. of Chicago Press.

Shapiro, C. (2001). Navigating the Patent Thicket: Cross Licenses, Patent Pools, and Standard Setting. In Innovation Policy and the Economy, Volume 1. National Bureau of Economic Research.

Shapiro, C. (2010). Injunctions, Hold-Up, and Patent Royalties. American Law and Economics Review 12(2), 280-318.

Shapiro, C. and M. A. Lemley (2020). The role of antitrust in preventing patent holdup. University of Pennsylvania Law Review 168, 1-44.

Sidak, G. (2018). Injunctive Relief and the FRAND Commitment in the United States. In J. Contreras (Ed.), Cambridge Handbook of Technical Standardization Law. Cambridge University Press.

Spier, K. E. (2007). Litigation. In The Handbook of Law and Economics (1st ed.)., Chapter 4. North Holland.

Teece, D. J. (2018). Profiting from Innovation in the Digital Economy: Enabling Technologies, Standards, and Licensing Models in the Wireless World. Research Policy 47, 1367-1387.

Williamson, O. E. (1975). Markets and Hierarchies, Analysis and Antitrust. New York: The Free Press.

Williamson, O. E. (1976). Franchise Bidding for Natural Monopolies-in General and with Respect to CATV. The Bell Journal of Economics 7(1), 73-104. 


\section{Online Appendix}

\section{A Appendix: Coding of Opportunistic Behaviors}

In this appendix we provide representative examples of the methodology used to code the measures of opportunistic conduct listed in Table 1 in the main text. All measures but one (Parallel ITC litigation) were coded following a thorough review of the pleadings and motions filed in each case asserting each relevant patent. As the examples below demonstrate, during this review we made note of all specific, factually-supported allegations or arguments made in the course of litigation indicating that the patent enforcer may have engaged in opportunistic conduct, while at the same time ignoring generic allegations of unspecified misconduct and boilerplate assertions of the applicability of relevant defenses.

Threats to sue customers: This measures indicates whether, in relation to each patentparty-level assertion, the accused infringer alleged (with specific factual support provided) that the patent enforcer attempted to induce the accused infringer to enter into a license by involving its customers in the dispute. In one representative example, the accused infringer pled that "in a blatant attempt to force [us] to pay excessive non-FRAND rates, [patent enforcer] reached out to [our] customers and downstream manufacturers, ${ }^{40}$ and in another, the alleged infringer accused the patent enforcer of making "false and defamatory statements ... during meetings with [potential customers] ... [including] that [accused infringer's] products infringed [patent enforcer's] patents, ...that [accused infringer] could not sell noninfringing products[,] ...that [patent enforcer] would utilize this lawsuit to put [accused infringer] out of business[, and] ... that this lawsuit would prevent [accused infringer] from being able to make an initial public stock offering.' 41

Parallel ITC litigation: This measure indicates whether, in relation to each patentparty-level assertion, a search of DocketNavigator ${ }^{42}$ revealed that the patent enforcer filed a parallel complaint with the U.S. International Trade Commission requesting that the accused infringer's products be excluded from importation into the U.S. because they infringe the relevant patent.

Relevant litigation abroad: This measure indicates whether, in relation to each patentparty-level assertion, the accused infringer alleged (with specific factual support provided) that the patent enforcer attempted to induce the accused infringer to enter into a license by pursuing parallel litigation in one or more foreign jurisdictions. ${ }^{43}$ In one rep-

\footnotetext{
${ }^{40}$ See, e.g., Compl. at 27, U-Blox AG v. Interdigital, Inc., No. 3:19-cv-00001 (S.D. Cal. Jan. 1, 2019)

${ }^{41}$ Answer at 49, Genband US LLC v. Metaswitch Networks Corp., No. 2:14-cv-00033 (E.D. Tex. filed July 7, 2014).

${ }^{42}$ https://brochure.docketnavigator.com/

${ }^{43}$ We did not search databases of foreign patent litigation to identify parallel foreign cases. Few such databases exist, and those that do exist are typically incomplete in temporal and/or geographic coverage.
} 
resentative example, the accused infringer pled that "the German subsidiary of [patent enforcer] initiated patent infringement suits in Germany against [accused infringer] based on German counterparts to the Patents-in-Suit [and] . . . . further suggested that a license covering just Germany would not be acceptable. 44

Exhaustion: This measure indicates whether, in relation to each patent-party-level assertion, the accused infringer alleged (with specific factual support provided) that the asserted patent was "exhausted" - i.e., that the patent was, in fact, already licensed by an upstream supplier or was covered by a license that the accused infringer negotiated in the past with a prior owner or licensor of the relevant patent. While generic assertions of exhaustion or license are commonly pled in patent cases, we limit our measure to allegations that identify specific prior agreements or specific upstream suppliers believed to hold a license. For example, we did not make note of common, generic "placeholder" allegations such as: "On information and belief, some or all of Defendant's accused products are licensed under the patent-in-suit and/or subject to the doctrines of patent exhaustion and implied license." Rather, the cases that we identify as pleading exhaustion included allegations such as: "Dolby's claims are barred by license, including a license of the patents-in-suit pursuant to a license agreement between Research In Motion Limited and Via Licensing Corporation.'45

No disclosure: This measure indicates whether, in relation to each patent-party-level assertion, the accused infringer argued or alleged (with specific factual support provided) that the patent enforcer holder improperly attempted to withhold evidence of the market value of a license to the relevant patent. In a representative example, the accused infringer pled (following a lengthy recitation of facts) that the patent enforcer "[r]epeatedly refused to provide [accused infringer] with the information .... needed to meaningfully assess [patent enforcer's] infringement allegations and ... RAND compliance. ${ }^{46}$

EMVR vs. SSPPU: This measure indicates whether, in relation to each patent-partylevel assertion, the accused infringer argued or alleged (with specific factual support provided) that the patent enforcer holder improperly sought to base the royalty owed on the entire market value of the accused end product. In one representative example, the accused infringer pled that "[patent enforcer] does not offer any licenses to cover component-part products, and instead pursues inflated royalties by licensing end-user devices only . ... . [and] [patent enforcer] maintained this position even after [accused infringer] ... repeatedly requested that Sisvel offer a license on FRAND terms to cover component parts. 477 In another, it was alleged that "[patent enforcer] has discriminato-

\footnotetext{
${ }^{44}$ Compl. at 5-6, HTC Corp. v. Acacia Research Corp., No. 2:15-cv-01510 (E.D. Tex. March 9, 2015).

${ }^{45}$ Answer at 9, Dolby Int'l AB v. Research in Motion Ltd., No. 3:11-cv-02931 (N.D. Cal. Aug. 5, 2011). See also Answer at 17, Genband US LLC v. Metaswitch Networks Corp., No. 2:14-cv-00033 (E.D. Tex. July 7, 2014) ("[B]y their participation in the PacketCable IPR agreements, GENBAND and Nortel and its affiliates have granted to all PacketCable signatories, including Metaswitch, a fully-paid, royalty-free, non-exclusive license (with a sublicense to end-users of licensed products) to their patents and other intellectual property practiced through compliance with the PacketCable specifications and technology.").

${ }^{46} \mathrm{Am}$. Answer at 38-42, Nokia Tech. Oy v. Apple, Inc., No. 2:16-cv-01440 (E.D. Tex March 20, 2017).

${ }^{47}$ Answer to 2d Am. Compl. at 18-19, Sisvel Int'l SA v. Dell, Inc., No. 1:19-cv-01247 (D. Del. May 4,
} 
rily chosen [accused infringer's] product line and other multi-function, many-featured products and software ...for the purpose of extracting unreasonable royalties [and] ... [patent enforcer's] Corporate Vice President Intellectual Property stated that a royalty for a license to its identified patents must be based on 'the price of the end product (e.g., each [gaming system], each PC/laptop, each smartphone, etc.) and not on component [operating system] software." 48

Prior licenses not comparable: This measure indicates whether, in relation to each patent-party-level assertion, the accused infringer argued or alleged (with specific factual support provided) that the patent enforcer holder improperly sought to calculate the royalty owed by reference to a not-reasonably-comparable prior licenses. In one representative example, an order from the court reveals that "Defendants contend that [patent enforcer's interpretation] of [third party] licenses is unreliable because [it] does not account for the technological and economic differences between the hypothetical and actual licenses ... [including] that the [third party] licenses involve royalties for third-party handset sales, whereas the hypothetical license involves functionality in the base stations and the baseband processor in the handsets ... [and] that comparing one group of patents that is representative of thousands of patents to the six patents-in-suit ignores the value of the vast majority of patents in the portfolio.' 49 In another, the record shows that the accused infringer "argues that [the patent enforcer's] reliance on the two [third party licensing] proposals is flawed ... [because] the two [third party] proposals substantially differ from the ultimate agreement reached by [the patent enforcer and the third party], almost by a factor of ten.'50

Injunction: This measure indicates whether, in relation to each patent-party-level assertion, the patent enforcer specifically requested an injunction in the complaint (or counterclaim) alleging infringement of the relevant patent. In coding this measure, we did not count broad, boilerplate requests for "such other and further relief as the Court deems just and proper." Instead, the measure is limited to pleadings that expressly request, for example, "[a]n order enjoining [the accused infringer] and its officers, agents, servants and employees, privies, and all persons in active concert or participation with it, from further infringement of said [patents]."

Untimely declaration: This measure indicates whether, in relation to each SEP-partylevel assertion, the accused infringer alleged (with specific factual support provided) that the SEP enforcer (or its predecessor-in-interest) failed to disclose the SEP to the standard-setting organization until after the standard's adoption (or initially declared the asserted patent non-essential prior to the standard's adoption), despite actively participating in the selection of technology for inclusion in the standard. In one representative example, it was alleged that "four days after the filing of the Reissue Application

\footnotetext{
2020).

${ }^{48}$ Answer at 28/29, Motorola Mobility, Inc. v. Microsoft Corp., No. 3:10-cv-00699 (W.D. Wis.).

${ }^{49}$ Intellectual Ventures II, LLC v. Sprint Spectrum, LP, No. 2:17-cv-00662, at*5-6 (E.D. Tex. April 26, 2019).

${ }^{50}$ Saint Lawrence Comm'ns, LLC v. ZTE Corp., No. 2:15-cv-00349, at *3, *8 (E.D. Tex. Feb. 21, 2017).
} 
which later issued as the [asserted SEP], [the SEP enforcer] submitted [a] letter to the chairman of the 802.11 working group stating, inter alia, that [none of its] "patent[s] are necessary for the implementation of devices incorporating the IEEE802.11b draft standard' ... [and when] [t] he IEEE 802.11 working group met again in November 1998 .... [the SEP enforcer's] president and CEO ... continued to represent that it believed that the Reissue Application was not necessary to the practice of 802.11b. 51 And in another, "at the time [the asserted SEPs' original owner] was seeking to have the SSOs incorporate its proposal into the CDMA2000 Standards, [the original owner] (including one or more of its employee inventors) knew that it was simultaneously seeking patent coverage . . . [of] its technical proposal and/or the draft CDMA2000 Standards" but "did not inform 3GPP2 or TTA until November 2008 that they believe that the [7 asserted SEPs] may fully or partially cover elements of, or be essential or potentially essential to the CDMA2000 Standards. $\sqrt[52]{52}$

Overdeclaration: This measure indicates whether, in relation to each SEP-party-level assertion, the accused infringer alleged (with specific factual support provided) that the SEP enforcer engaged in "overdeclaration" by requiring licensees-as a condition for obtaining a license to relevant SEPs — to additionally pay royalties for rights to patents that were either not essential to the relevant standardized technology generally or not relevant to the accused infringer's specific products. One representative allegation, for example, stated that the SEP licensor "has periodically removed expired patents and submitted new patents to extend the lifespan of the ATSC patent portfolio ... without notice or comment from licensees and without independent third-party evaluation to ensure essentiality," including "46 patents [added] since October 2015 that relate to broadcasting and transmitting over-the-air signals to ATSC-compliant receivers ... zero [of which] are required for [the accused infringer] (or any other DTV manufacturer or seller) to make its DTVs ATSC compliant because its DTVs do not broadcast signals. $\sqrt[53]{53}$

Discriminatory license: This measure indicates whether, in relation to each SEPparty-level assertion, the accused infringer alleged (with specific factual support provided) that the SEP enforcer sought to license the patent on a discriminatory basis in violation of FRAND commitments. Again, while generic allegations of FRAND violations were common, we limited our selection to only those cases that provided specific factual support for the allegation that the SEP enforcer's pre-suit royalty demands were discriminatory or exclusionary. In one representative example it was alleged that the

\footnotetext{
${ }^{51}$ Answer at 17, WI-LAN, Inc. v. Apple, Inc., No. 6:11-cv-00453 (E.D. Tex. Nov. 4, 2011).

${ }^{52}$ Answer at 44, SPH America, LLC v. AT\&T Mobility, LLC, No. 3:13-cv-02318 (S.D. Cal. Aug. 18, 2014).

${ }^{53}$ Compl. at 21-22, Haier America Trading, LLC v. Samsung Electronics Co., No. 1:17-cv-00921 (N.D.N.Y. Aug. 21, 2017). See also, HP, Inc.'s Answer, Audio MPEG, Inc. v. HP, Inc., No. 2:15-cv-00073 (E.D. Va. Aug. 19, 2015) (pleading at 26 that "on information and belief, in addition to patents directed at the MP3 Standard, the SISVEL Patent Pool includes patents directed at standards clearly unrelated to and therefore not essential to MP3 Technology, including MPEG Audio Layers I and II, MPEG-2 patents, and other technology different from and unrelated to MP3 Technology," and also at 36 that "[o]ver half of the patents in the SISVEL Patent Pool have claims directed solely at encoders and/or transmission systems, neither of which relates to all of HP's products, which are mostly MP3 decoders").
} 
SEP licensor had "offered the license to the [asserted] patents at different, discriminatory prices ... [with] [t] he apparent purpose of ... rais[ing] costs to competitors ... in the MP2-audio-enabled product and MP3-audio-enabled product markets (which includes [accused infringer]), and to drive out competition in the MP2-audio-enabled product and MP3-audio-enabled product markets. ${ }^{54}$

Check of coding methodology: As a check of our coding methodology's replicability, we asked an additional third-party coder (an experienced law student research assistant who had completed an internship working on U.S. patent litigation) to review a subset of our data. For this check, we selected (without notifying the additional coder of our selection criteria) a sample of more than 1,100 patent-party level assertions previously identified as exhibiting at least one measure of opportunism. For each assertion in this subset, we asked the research assistant to code all five allegation-based measures that are shared by SEP and NSEP cases: threats to sue customers, relevant litigation abroad, exhaustion, no disclosure, EMVR vs. SSPPU, and prior licenses not comparable. A comparison of the research assistant's coding with our own produces a Cohen's Kappa of 0.87. A Kappa above 0.8 has been characterized in the literature as "strong" to "almost perfect" (Landis and Koch, 1977). We additionally note that this Kappa was achieved in a replicability check restricted to a subset of cases and measures that are both particularly important to our analysis and particularly likely to lead to disagreement.

${ }^{54}$ Dell, Inc.'s Answer at 46, Audio MPEG, Inc. v. HP, Inc., No. 2:15-cv-00073 (E.D. Va. July 15, 2016) 


\section{B Appendix: Control Variables}

In this Appendix we provide an overview of the variables used in the regression analysis:

- $\mathbf{P}$ is NPE: $=1$ if the plaintiff is an NPE.

- P size: 5 categories, SME ( $<$ US $\$ 100 \mathrm{M}$ rev. or $<500$ employees), Smaller Large (US\$1 B rev. > US $\$ 100 \mathrm{M}$, or 4,000 > employees $>500$ ), Medium Large (US\$10 $\mathrm{B}>$ rev. $>$ US $\$ 1 \mathrm{~B}$, or $30,000>$ employees $>4,000$ ), Very Large (US $\$ 100 \mathrm{~B}>$ rev. $>$ US $\$ 10$ B, or 200,000 > employees $>30,000$ ), Largest ( $>$ US $\$ 100 \mathrm{~B}$ rev. or $>200,000$ employees).

- D size: 5 categories, SME ( $<\mathrm{US} \$ 100 \mathrm{M}$ rev. or $<500$ employees), Smaller Large (US\$1 B rev. > US $\$ 100 \mathrm{M}$, or 4,000 > employees > 500), Medium Large (US $\$ 10$ $\mathrm{B}>$ rev. $>$ US $\$ 1 \mathrm{~B}$, or $30,000>$ employees $>4,000$ ), Very Large (US $\$ 100 \mathrm{~B}>$ rev. > US $\$ 10 \mathrm{~B}$, or $200,000>$ employees $>30,000$ ), Largest (> US $\$ 100 \mathrm{~B}$ rev. or $>200,000$ employees).

- $\mathbf{P}$ is both $\mathbf{P}$ and $\mathbf{D}:=1$ if the plaintiff appears as both plaintiff and defendant in our dataset of SEP court cases between 2010 and 2019.

- $\mathbf{D}$ is both $\mathbf{P}$ and $\mathbf{D}:=1$ if the defendant appears as both plaintiff and defendant in our dataset of SEP court cases between 2010 and 2019.

- P upstream of $\mathbf{D}:=1$ if the plaintiff is upstream of the defendant.

- $\mathbf{P}$ and $\mathbf{D}$ competitors: $=1$ if the plaintiff and defendant are product market competitors.

- D prior licensee of $\mathbf{P}:=1$ if the plaintiff and defendant had a prior licensing agreement.

- D technology user: $=1$ if the defendant use the infringing technology to sell something (significantly) unrelated, $=0$ if the defendant sell the infringing technology.

- Technology in component: $=1$ if the infringement substantially occurs in a component of the accused product, or the infringement occurs in some product/service that the defendant buys from an upstream vendor; $=0$ if the accused product is, itself, a component.

- Declaratory action: $=1$ if the case is a declaratory action as opposed to an infringement action.

- D answer count: count of answers filed by the defendant.

- MTD: $=1$ if a motion to dismiss was filed.

- MSJ: $=1$ if a motion for summary judgment was filed. 
- Case consolidated: $=1$ is several separate court cases were consolidated by the court into a single case.

- Patent reassigned: $=1$ if the patent has been re-assigned at least once at any point between independent entities. 


\section{Appendix: Figures}

Figure A-1: Case outcomes (at the patent-party-level) of SEPs vs NSEPs

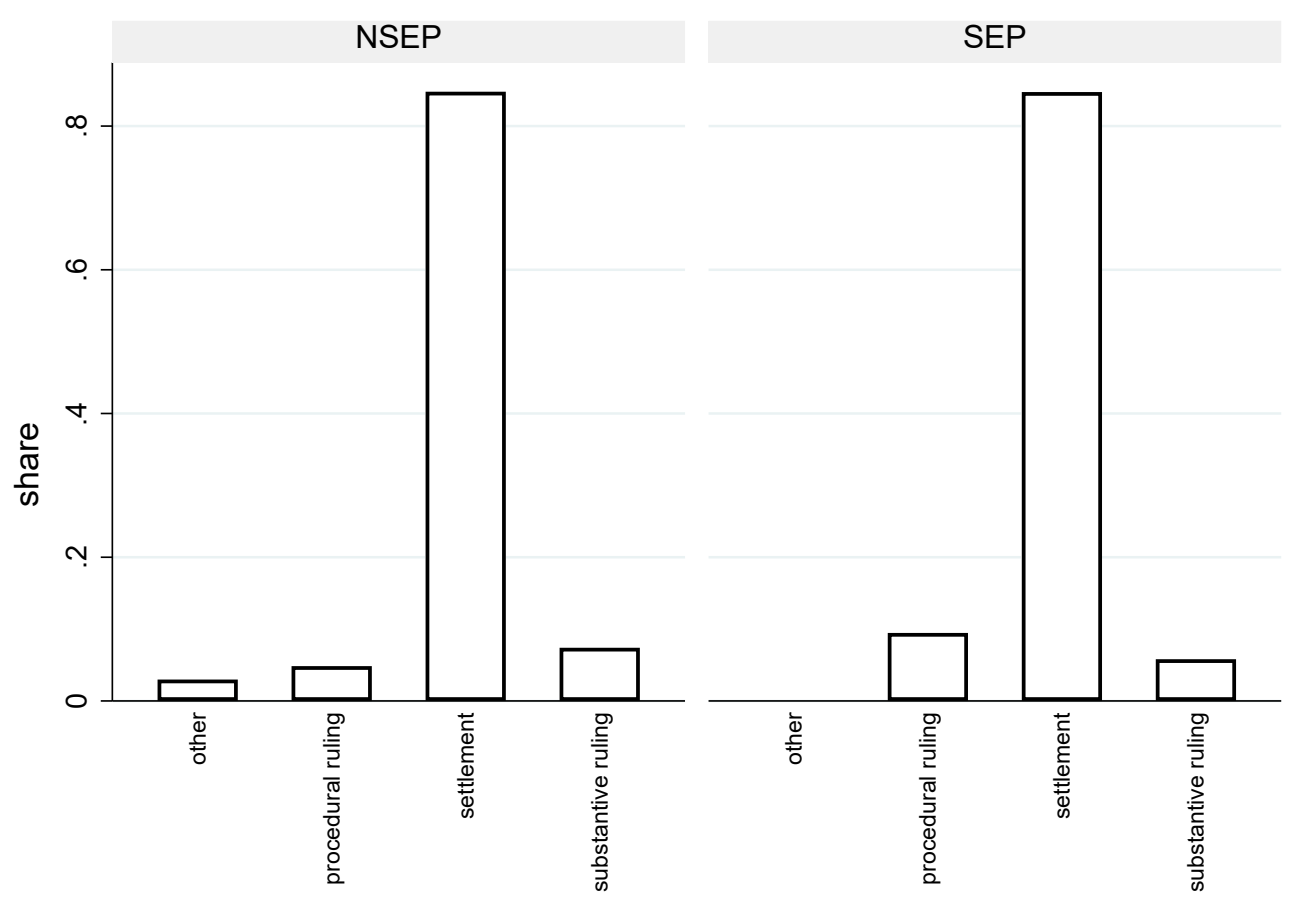

Note: The graph shows case outcomes at the patent-party-case level of cases that involve either SEPs or NSEPs between 2010 and 2019. 


\section{Appendix: Tables}

Table A-1: Comparison of patent characteristics between SEP and NSEP matched sample

\begin{tabular}{lcc}
\hline Outcome: & \multicolumn{2}{c}{ SEP } \\
\hline & -0.002 & 0.007 \\
\hline (1) IPC 4 count & $(0.005)$ & $(0.007)$ \\
& -0.0005 & -0.0003 \\
(2) Number of claims & $(0.0007)$ & $(0.0007)$ \\
& $0.007^{* * *}$ & $0.007^{* * *}$ \\
(3) Family size & $(0.0009)$ & $(0.001)$ \\
& $0.040^{* * *}$ & $0.041^{* * *}$ \\
(4) Number inventors & $(0.009)$ & $(0.010)$ \\
& 0.0002 & 0.0003 \\
(5) Forward cites & $(0.0002)$ & $(0.0002)$ \\
& -0.0007 & $-0.001^{*}$ \\
(6) Backward cites & $(0.0005)$ & $(0.0007)$ \\
& -0.0003 & 0.0005 \\
(7) NPL cites & $(0.0009)$ & $(0.001)$ \\
\hline Case filing year & No & Yes \\
Patent filing year & No & Yes \\
\hline $\mathrm{R}^{2}$ & 0.169 & 0.210 \\
Observations & 754 & 754 \\
\hline
\end{tabular}

Notes: Unit of observation at the patent-level; OLS coefficients shown; robust standard errors; IPC 4: International Patent Classification subclasses; NPL: non-patent literature; * significant at $10 \%, * *$ at $5 \%$, *** at $1 \%$. 
Table A-2: Opportunistic behavior by patent enforcer by SEP status - conditional on at least 1 answer filed by defendant

\begin{tabular}{clccc}
\hline & Opportunistic behavior & SEP & NSEP & Diff. \\
\hline & & $(1)$ & $(2)$ & $(3)$ \\
\hline 1 & Any opportunistic behavior & 76.99 & 68.26 & $8.72^{* * *}$ \\
\hline 2 & Licensee's litigation costs & 6.14 & 8.98 & $2.83^{* *}$ \\
\cline { 2 - 5 } 2.1 & Threats to sue customers & 2.22 & 2.19 & -0.03 \\
2.2 & Parallel ITC litigation & 3.92 & 6.78 & 2.86 \\
2.3 & Relevant litigation abroad & 0.13 & 0 & 0.13 \\
\hline 3 & Licensee's potential loss & 31.50 & 9.78 & $21.72^{* * *}$ \\
\cline { 2 - 5 } 3.1 & Exhaustion & 21.96 & 6.58 & $15.37^{* * *}$ \\
3.2 & No disclosure & 0.91 & 0.79 & 0.11 \\
3.3 & EMVR vs. SSPPU & 12.28 & 5.18 & $7.09^{* * *}$ \\
3.4 & Prior licenses not comparable & 8.62 & 4.99 & $3.63^{* * *}$ \\
\hline 4 & Injunction & 39.47 & 63.07 & $-23.59^{* * *}$ \\
\hline 5 & SEP-specific & 34.37 & NA & \\
\cline { 2 - 5 } 5.1 & Untimely declaration & 21.04 & NA & \\
5.2 & Overdeclaration & 14.50 & NA & \\
5.3 & Discriminatory license & 10.06 & NA & \\
\hline & Total cases & 765 & 501 & \\
\hline
\end{tabular}

Notes: The table only includes cases where the defendant filed at least one response to the complaint; SEP: standard essential patent; NSEP: matched non-standard essential patent. Unit of observation at the patent-party-case level; 1) In the answer (and/or other, later filings) did the accused infringer (specifically) allege that the patent enforcer (or its predecessor) engaged in some kind of opportunistic behavior or something that might constitute a FRAND violation? 2) Licensee's litigation costs: 2.1) Did the patent enforcer bring the accused infringer's customers in the licensing dispute, either by contacting them or threatening to sue them or actually suing them? 2.2) Did the patent enforcer initiate litigation against the accused infringer at the ITC in parallel to the district court litigation?; 2.3) Did the patent enforcer initiate litigation against the accused infringer in another country - e.g., in an attempt to get an injunction in Germany when it couldn't get an injunction in the US? 3) Licensee's potential loss: 3.1) Did the accused infringer (specifically) allege that the patent was already licensed (often by an upstream component supplier)? 3.2) Did the accused infringer make a specific allegation that the patent enforcer simply refused to disclose the terms of prior licenses with similarly situated companies? 3.3) Did the accused infringer argue that the patent enforcer was improperly trying to base the royalty owed on the price of the end product (using the EMVR), rather than the price of a component/module (the SSPPU). 3.4) Did the accused infringer argue that the patent enforcer was improperly trying to base the royalty owed on prior licenses that were not really comparable (due to differences in patents, duration, geographic scope, licensee type, etc). 4) In the complaint (or counterclaim) did the patent enforcer request an injunction? 5) SEP-specific: 5.1) Did the accused infringer argue that the patent enforcer (or its predecessor) did not disclose the SEP to the SSO until after the technology was adopted? 5.2) Did the accused infringer argue that the patent enforcer was trying to force the accused infringer to license (along with SEPs) additional patents that were not actually essential to the standard? 5.3) Did the accused infringer make a specific allegation that the patent enforcer adopted discriminatory or exclusionary licensing terms or practices? 
Table A-3: Determinants of opportunistic behavior by patent enforcer - conditional on at least 1 answer filed by defendant

\begin{tabular}{|c|c|c|c|c|c|c|c|c|c|}
\hline \multirow[t]{2}{*}{ Outcome: } & \multicolumn{2}{|c|}{ Any } & \multicolumn{2}{|c|}{ Costs } & \multicolumn{2}{|c|}{ Loss } & \multicolumn{2}{|c|}{ Injunction } & \multirow{2}{*}{$\frac{\text { SEP-specific }}{\text { SEP }}$} \\
\hline & SEP & SEP/NSEP & SEP & SEP/NSEP & SEP & SEP/NSEP & SEP & SEP/NSEP & \\
\hline & (1) & (2) & (3) & (4) & (5) & (6) & (7) & (8) & (9) \\
\hline (1) SEP & & $\begin{array}{c}0.064 \\
(0.074)\end{array}$ & & $\begin{array}{l}-0.005 \\
(0.023)\end{array}$ & & $\begin{array}{l}0.112^{* * *} \\
(0.046)\end{array}$ & & $\begin{array}{c}-0.183^{* *} \\
(0.078)\end{array}$ & \\
\hline \multicolumn{10}{|l|}{$P / D$ characteristics } \\
\hline (2) P is NPE & $\begin{array}{c}-0.261^{* *} \\
(0.127)\end{array}$ & $\begin{array}{c}0.107 \\
(0.130)\end{array}$ & $\begin{array}{c}-0.627^{* * * *} \\
(0.095)\end{array}$ & $\begin{array}{c}0.049 \\
(0.041)\end{array}$ & $\begin{array}{c}0.174 \\
(0.139)\end{array}$ & $\begin{array}{l}-0.015 \\
(0.053)\end{array}$ & $\begin{array}{c}-0.019 \\
(0.123)\end{array}$ & $\begin{array}{c}0.016 \\
(0.153)\end{array}$ & $\begin{array}{c}0.767^{* * * *} \\
(0.135)\end{array}$ \\
\hline (3) P size & $\begin{array}{l}0.101^{*} \\
(0.054)\end{array}$ & $\begin{array}{l}-0.053 \\
(0.039)\end{array}$ & $\begin{array}{c}0.039 \\
(0.037)\end{array}$ & $\begin{array}{l}-0.073^{*} \\
(0.043)\end{array}$ & $\begin{array}{l}0.163^{* *} \\
(0.081)\end{array}$ & $\begin{array}{c}0.017 \\
(0.036)\end{array}$ & $\begin{array}{l}-0.012 \\
(0.065)\end{array}$ & $\begin{array}{c}-0.012 \\
(0.043)\end{array}$ & $\begin{array}{c}0.247^{* * * *} \\
(0.040)\end{array}$ \\
\hline (4) D size & $\begin{array}{l}0.040^{*} \\
(0.022)\end{array}$ & $\begin{array}{c}0.030 \\
(0.023)\end{array}$ & $\begin{array}{l}-0.020 \\
(0.013)\end{array}$ & $\begin{array}{c}-0.004 \\
(0.007)\end{array}$ & $\begin{array}{c}0.079 * * * \\
(0.017)\end{array}$ & $\begin{array}{c}0.046^{* * *} \\
(0.011)\end{array}$ & $\begin{array}{l}-0.003 \\
(0.017)\end{array}$ & $\begin{array}{c}0.016 \\
(0.023)\end{array}$ & $\begin{array}{l}0.042^{* *} \\
(0.016)\end{array}$ \\
\hline (5) $P$ is both $P$ and $D$ & $\begin{array}{l}-0.061 \\
(0.081)\end{array}$ & $\begin{array}{c}0.071 \\
(0.069)\end{array}$ & $\begin{array}{l}-0.073 \\
(0.053)\end{array}$ & $\begin{array}{c}0.018 \\
(0.066)\end{array}$ & $\begin{array}{c}0.122 \\
(0.098)\end{array}$ & $\begin{array}{l}0.156^{* * *} \\
(0.071)\end{array}$ & $\begin{array}{l}-0.026 \\
(0.088)\end{array}$ & $\begin{array}{c}0.010 \\
(0.064)\end{array}$ & $\begin{array}{l}-0.036 \\
(0.052)\end{array}$ \\
\hline (6) $D$ is both $P$ and $D$ & $\begin{array}{l}-0.007 \\
(0.035)\end{array}$ & $\begin{array}{c}0.020 \\
(0.032)\end{array}$ & $\begin{array}{c}0.064 * * * \\
(0.022)\end{array}$ & $\begin{array}{c}0.060 * * * * \\
(0.017)\end{array}$ & $\begin{array}{c}0.198^{* * * *} \\
(0.041)\end{array}$ & $\begin{array}{c}0.156^{* * * *} \\
(0.029)\end{array}$ & $\begin{array}{l}0.071 * * \\
(0.034)\end{array}$ & $\begin{array}{c}0.103 * * * \\
(0.036)\end{array}$ & $\begin{array}{c}-0.201^{* * *} \\
(0.031)\end{array}$ \\
\hline (7) $P$ upstream of D & $\begin{array}{l}-0.063 \\
(0.100)\end{array}$ & $\begin{array}{c}0.038 \\
(0.083)\end{array}$ & $\begin{array}{c}0.022 \\
(0.074)\end{array}$ & $\begin{array}{c}0.051 \\
(0.056)\end{array}$ & $\begin{array}{c}0.014 \\
(0.151)\end{array}$ & $\begin{array}{l}0.163^{*} \\
(0.095)\end{array}$ & $\begin{array}{l}-0.056 \\
(0.109)\end{array}$ & $\begin{array}{l}0.166^{*} \\
(0.090)\end{array}$ & $\begin{array}{l}0.178^{* *} \\
(0.086)\end{array}$ \\
\hline (8) P and D competitors & $\begin{array}{l}-0.149^{*} \\
(0.083)\end{array}$ & $\begin{array}{c}0.001 \\
(0.074)\end{array}$ & $\begin{array}{c}0.042 \\
(0.071)\end{array}$ & $\begin{array}{c}0.096 \\
(0.058)\end{array}$ & $\begin{array}{c}-0.367^{* \ldots * *} \\
(0.135)\end{array}$ & $\begin{array}{l}-0.137^{*} \\
(0.078)\end{array}$ & $\begin{array}{c}-0.245^{* * * *} \\
(0.090)\end{array}$ & $\begin{array}{c}-0.022 \\
(0.082)\end{array}$ & $\begin{array}{c}-0.007 \\
(0.069)\end{array}$ \\
\hline (9) D prior licensee of $P$ & $\begin{array}{c}0.226^{* * * *} \\
(0.067)\end{array}$ & $\begin{array}{c}0.237^{* * * *} \\
(0.059)\end{array}$ & $\begin{array}{c}0.017 \\
(0.041)\end{array}$ & $\begin{array}{c}-0.076^{* * *} \\
(0.038)\end{array}$ & $\begin{array}{l}0.144^{*} \\
(0.073)\end{array}$ & $\begin{array}{c}0.203^{* * * *} \\
(0.056)\end{array}$ & $\begin{array}{c}0.302^{* * * *} \\
(0.065)\end{array}$ & $\begin{array}{l}0.121^{*} \\
(0.064)\end{array}$ & $\begin{array}{c}-0.198^{* * * *} \\
(0.059)\end{array}$ \\
\hline (10) D technology user & $\begin{array}{c}-0.284^{* * * *} \\
(0.074)\end{array}$ & $\begin{array}{c}0.003 \\
(0.115)\end{array}$ & $\begin{array}{c}-0.095^{* *} \\
(0.041)\end{array}$ & $\begin{array}{c}-0.086^{* * * *} \\
(0.027)\end{array}$ & $\begin{array}{l}0.147^{*} \\
(0.088)\end{array}$ & $\begin{array}{l}0.159^{*} \\
(0.092)\end{array}$ & $\begin{array}{c}-0.052 \\
(0.075)\end{array}$ & $\begin{array}{c}0.094 \\
(0.113)\end{array}$ & $\begin{array}{c}-0.287^{* * *} \\
(0.072)\end{array}$ \\
\hline (11) Tech. in component & $\begin{array}{l}-0.006 \\
(0.078)\end{array}$ & $\begin{array}{c}-0.219 * * * \\
(0.066)\end{array}$ & $\begin{array}{c}0.008 \\
(0.049)\end{array}$ & $\begin{array}{c}0.021 \\
(0.037)\end{array}$ & $\begin{array}{c}-0.163 * * \\
(0.080)\end{array}$ & $\begin{array}{l}-0.061^{*} \\
(0.033)\end{array}$ & $\begin{array}{l}-0.177^{* *} \\
(0.075)\end{array}$ & $\begin{array}{c}-0.264 * * * \\
(0.074)\end{array}$ & $\begin{array}{c}0.053 \\
(0.068)\end{array}$ \\
\hline Case characteristics & & & & & & & & & \\
\hline (12) Declaratory action & $\begin{array}{l}0.193^{* *} \\
(0.094)\end{array}$ & $\begin{array}{c}0.006 \\
(0.081)\end{array}$ & $\begin{array}{c}0.153^{* * *} \\
(0.055)\end{array}$ & $\begin{array}{c}0.122 * * * \\
(0.044)\end{array}$ & $\begin{array}{c}-0.035 \\
(0.088)\end{array}$ & $\begin{array}{c}-0.131 * * \\
(0.052)\end{array}$ & $\begin{array}{c}-0.527^{* * * *} \\
(0.090)\end{array}$ & $\begin{array}{c}-0.406^{* * *} \\
(0.091)\end{array}$ & $\begin{array}{c}0.630^{* * *} \\
(0.089)\end{array}$ \\
\hline (13) MTD & $\begin{array}{c}0.326^{* * *} \\
(0.050)\end{array}$ & $\begin{array}{c}0.250^{* * * *} \\
(0.058)\end{array}$ & $\begin{array}{l}0.038^{*} \\
(0.021)\end{array}$ & $\begin{array}{l}-0.011 \\
(0.016)\end{array}$ & $\begin{array}{c}0.596^{* * * *} \\
(0.108)\end{array}$ & $\begin{array}{c}0.405^{* * *} \\
(0.078)\end{array}$ & $\begin{array}{c}0.183 \\
(0.173)\end{array}$ & $\begin{array}{c}0.131 \\
(0.102)\end{array}$ & $\begin{array}{c}0.184^{* * *} \\
(0.066)\end{array}$ \\
\hline (14) MSJ & $\begin{array}{c}0.212^{* * *} \\
(0.046)\end{array}$ & $\begin{array}{c}0.217^{* * * *} \\
(0.052)\end{array}$ & $\begin{array}{l}-0.033 \\
(0.023)\end{array}$ & $\begin{array}{l}-0.046^{* *} \\
(0.023)\end{array}$ & $\begin{array}{l}-0.008 \\
(0.055)\end{array}$ & $\begin{array}{c}0.053 \\
(0.056)\end{array}$ & $\begin{array}{c}0.041 \\
(0.048)\end{array}$ & $\begin{array}{l}-0.0007 \\
(0.054)\end{array}$ & $\begin{array}{c}0.238^{* * * *} \\
(0.053)\end{array}$ \\
\hline (15) Case consolidated & $\begin{array}{c}0.087 \\
(0.086)\end{array}$ & $\begin{array}{c}0.011 \\
(0.067)\end{array}$ & $\begin{array}{l}-0.043 \\
(0.028)\end{array}$ & $\begin{array}{c}-0.038^{* * *} \\
(0.017)\end{array}$ & $\begin{array}{l}0.105^{*} \\
(0.057)\end{array}$ & $\begin{array}{l}0.093^{* * *} \\
(0.047)\end{array}$ & $\begin{array}{l}-0.153^{* *} \\
(0.075)\end{array}$ & $\begin{array}{c}-0.161^{* * * *} \\
(0.058)\end{array}$ & $\begin{array}{c}0.230^{* * * *} \\
(0.062)\end{array}$ \\
\hline Patent characteristics & & & & & & & & & \\
\hline (16) Patent reassigned & $\begin{array}{c}-0.015 \\
(0.060)\end{array}$ & $\begin{array}{c}-0.086 \\
(0.054)\end{array}$ & $\begin{array}{c}-0.069 \\
(0.050)\end{array}$ & $\begin{array}{c}-0.036 \\
(0.035)\end{array}$ & $\begin{array}{c}0.200 * * * \\
(0.058)\end{array}$ & $\begin{array}{c}0.146^{* * *} \\
(0.041)\end{array}$ & $\begin{array}{c}-0.144^{* * *} \\
(0.045)\end{array}$ & $\begin{array}{c}-0.164^{* * * *} \\
(0.062)\end{array}$ & $\begin{array}{c}-0.019 \\
(0.050)\end{array}$ \\
\hline Case filing year & Yes & Yes & Yes & Yes & Yes & Yes & Yes & Yes & Yes \\
\hline $\mathrm{R}^{2}$ & 0.285 & 0.161 & 0.310 & 0.211 & 0.364 & 0.299 & 0.604 & 0.384 & 0.527 \\
\hline Observations & 765 & 1,266 & 765 & 1,266 & 765 & 1,266 & 765 & 1,266 & 765 \\
\hline
\end{tabular}

Notes: The table only includes cases where the defendant filed at least one response to the complaint; SEP: standard essential patent; NSEP: matched non-standard essential patent; Any: equal to one if any of the measures listed in Table 2 is equal to one; Costs: equal to one if any of the measures 2.1-2.3 listed in Table 2 is equal to one; Loss: equal to one if any of the measures 3.1-3.4 listed in Table 2 is equal to one; Injunction: equal to one if measure 4 listed in Table2 2 is equal to one; SEP-specific: equal to one if any of the measures 5.1-5.3 listed in Table 2 is equal to one. Unit of observation at the patent-party-case level; * significant at $10 \%, * *$ at $5 \%, * * *$ at $1 \%$. 
Table A-4: Opportunistic behavior and case outcomes - conditional on at least 1 answer filed by defendant

\begin{tabular}{|c|c|c|c|c|c|c|}
\hline \multirow[t]{2}{*}{ Outcome: } & \multicolumn{6}{|c|}{ Settlement $(0 / 1)$} \\
\hline & SEP & SEP/NSEP & SEP & SEP/NSEP & SEP & SEP/NSEP \\
\hline & (1) & (2) & (3) & (4) & (5) & (6) \\
\hline Any opportunistic & $\begin{array}{c}-0.120^{* * *} \\
(0.024)\end{array}$ & $\begin{array}{l}0.168^{* *} \\
(0.073)\end{array}$ & & & & \\
\hline Any opportunistic $\times$ SEP & & $\begin{array}{c}-0.227 * * * \\
(0.079)\end{array}$ & & & & \\
\hline Costs & & & $\begin{array}{c}0.066 \\
(0.043)\end{array}$ & $\begin{array}{c}0.198 * * * \\
(0.061)\end{array}$ & & \\
\hline Costs $\times$ SEP & & & & $\begin{array}{c}-0.154^{* *} \\
(0.073)\end{array}$ & & \\
\hline Loss & & & & & $\begin{array}{c}-0.128 * * * \\
(0.032)\end{array}$ & $\begin{array}{c}-0.071 \\
(0.089)\end{array}$ \\
\hline Loss $\times$ SEP & & & & & & $\begin{array}{c}0.016 \\
(0.099)\end{array}$ \\
\hline SEP & & $\begin{array}{c}0.244^{* * *} \\
(0.074)\end{array}$ & & $\begin{array}{l}0.105^{* *} \\
(0.044)\end{array}$ & & $\begin{array}{l}0.098 * * \\
(0.044)\end{array}$ \\
\hline Covariates & Yes & Yes & Yes & Yes & Yes & Yes \\
\hline Case filing year & Yes & Yes & Yes & Yes & Yes & Yes \\
\hline $\mathrm{R}^{2}$ & 0.581 & 0.218 & 0.567 & 0.356 & 0.584 & 0.351 \\
\hline Observations & 765 & 1,266 & 765 & 1,266 & 765 & 1,266 \\
\hline
\end{tabular}

Notes: The table only includes cases where the defendant filed at least one response to the complaint; SEP: standard essential patent; NSEP: matched non-standard essential patent. Any: equal to one if any of the measures listed in Table 2 is equal to one; Costs: equal to one if any of the measures 2.1-2.3 listed in Table 2 is equal to one; Loss: equal to one if any of the measures 3.1-3.4 listed in Table 2 is equal to one. Covariates listed in Online Appendix B Unit of observation at the patent-party-case level; $*$ significant at $10 \%, * *$ at $5 \%, * * *$ at $1 \%$. 